\title{
Sedimentary facies analysis of the fluvial systems in the Siwalik Group, Karnali River section, Nepal Himalaya, and their significance for understanding the paleoclimate and Himalayan tectonics
}

\author{
*Ashok Sigdel ${ }^{1}$, Tetsuya Sakai ${ }^{2}$ \\ ${ }^{1}$ Soil, Rock and Concrete Laboratory, Nepal Electricity Authority \\ Swoyambhu, Kathmandu, Nepal \\ ${ }^{2}$ Department of Geoscience, Shimane University, Matsue 690-8504, Japan \\ ( ${ }^{\star}$ Email: ashoksigdel80@gmail.com)
}

\begin{abstract}
Fluvial sediments of the Siwalik successions in the Himalayan Foreland Basin are one of the most important continental archives for the history of Himalayan tectonics and climate change during the Miocene Period. This study reanalyzes the fluvial facies of the Siwalik Group along the Karnali River, where the large paleo-Karnali River system is presumed to have flowed. The reinterpreted fluvial system comprises fine-grained meandering river (FA1), flood-flow dominated meandering river with intermittent appearance of braided rivers (FA2), deep and shallow sandy braided rivers (FA3, FA4) to gravelly braided river (FA5) and finally debris-flow dominated braided river (FA6) facies associations, in ascending order. Previous work identified sandy flood-flow dominated meandering and anastomosed systems, but this study reinterprets these systems as a flood-flow dominated meandering river system with intermittent appearance of braided rivers, and a shallow sandy braided system, respectively. The order of the appearance of fluvial depositional systems in the Karnali River section is similar to those of other Siwalik sections, but the timing of the fluvial facies changes differs. The earlier appearance (3-4 Ma) of the flood-flow dominated meandering river system in the Karnali River section at about 13.5 Ma may have been due to early uplift of the larger catchment size of the paleo-Karnali River which may have changed the precipitation pattern i.e. intensification of the Indian Summer Monsoon. The change from a meandering river system to a braided river system is also recorded 1 to 3 Ma earlier than in other Siwalik sections in Nepal. Differential and diachronous activities of the thrust systems could be linked to change in catchment area as well as diachronous uplift and climate, the combination of which are major probable causes of this diachronity.
\end{abstract}

Keywords: Siwalik Group, Karnali River, large catchment system, flood-flow dominated meandering system, Indian Summer Monsoon

Received: 1 December 2015

Revision accepted: 7 April 2016

\section{INTRODUCTION}

The Siwalik Group is a fluvial deposit that accumulated in the ancient foreland basin formed in association with the uplift of the Himalayas generated by the collision of the Indian and Eurasian plates (Patriat and Achache 1984; Burbank 1992; Rowley 1996). The uplift of the Himalaya was accompanied by paleoclimatic changes, changes in weathering, erosion, and the style of fluvial systems which drained the mountains and deposited sediments in the foreland basin (Prakash et al. 1980; Tokuoka et al. 1990; Willis 1993; Zaleha 1997; Sharma et al. 2002; Kumar et al. 2003; 2004). The fluvial depositional systems in the Siwalik Group have been examined in several sections in Pakistan and India, as well as in Nepal (Willis 1993; Khan et al. 1997; Zaleha 1997; Kumar et al. 2003; 2004; Tokuoka et al. 1986, 1990, 1994; Hisatomi and Tanaka 1994; Nakayama and Ulak 1999; Ulak and Nakayama 2001). These studies reconstructed the fluvial systems changes from meandering to braided river systems from Lower to Upper Siwaliks and revealed that order of appearance of the fluvial systems was consistent but timing differed between sections. The parameters which affected these changes in fluvial systems are alluvial process (autocyclic) as well as allocyclic process, such as climate and tectonics of the hinterland (Willis 1993; Zaleha 1997).

The Siwalik Group in the Karnali River area of Nepal Himalaya (Fig. 1) has been the locus of a variety of studies (Gautam and Fujiwara 2000; Huyghe et al. 2001; Huyghe et al. 2005; Bernet et al. 2006; Szulc et al. 2006; Van der Beek et. al. 2006). These studies focused on petrography, isotopes and age dating, in efforts to understand the provenance of the sediments, tectonics, and their exhumation. The framework provided by these studies makes the area highly suitable for appraisal of paleoclimate and associated changes in fluvial depositional system. Huyghe et al. (2005) studied the depositional facies at a broad scale, and interpreted a similar order of development of the fluvial systems as in other areas, which was also mainly controlled by the climate and tectonics. Although many studies have examined the petrography, isotopes and age dating, no detailed depositional facies information at meter-scale is yet available for the Karnali River section.

In this study, we reappraise the fluvial facies classification of Huyghe et al. (2005) from the Karnali River area (Fig 1). We also compare the reconstructed fluvial systems with sedimentological, petrographic, and isotopic data from previous studies 
elsewhere in the Siwalik, to discuss the climatic change and Himalayan tectonics.

\section{GEOLOGICAL SETTING}

The Siwalik Group comprises a 16.0 Ma succession of synorogenic sediments derived from the main Himalayan Range (Gansser 1964; Upreti 1999). The Siwalik sediments are bounded by the Main Boundary Thrust (MBT) and the Main Frontal Thrust (MFT), which separate the group from the Lesser Himalaya to the north, and from the Indo-Gangatic plain to the south, respectively (Mugnier et al. 1999). The thickness of the Siwalik Group ranges from 4 to $6 \mathrm{~km}$.

This study targets the Siwalik Group exposed around the Karnali River section (Fig. 1). The traditional tripartite lithological division (Lower, Middle and Upper Siwalik) was previously applied in this area (DMG 1987, 2003; Mugnier et al. 1998, 1999). The age of this section ranges from 15.8 to 5.2 $\mathrm{Ma}$, as obtained by a paleomagnetic analysis by Gautam and Fujiwara (2000).

Structurally, the Siwalik Group in this area consists of two large belts (southern and northern) separated by the Main Dun Thrust (MDT), an extensive intra-Siwalik thrust (Mugnier et al. 1998). The southern belt is about $12 \mathrm{~km}$ wide, whereas the northern belt is about $6 \mathrm{~km}$ in N-S width. Sigdel et al. (2011) established the stratigraphy of the southern belt in this area, dividing it into the Chisapani Formation (equivalent to the
Lower Siwalik, $2045 \mathrm{~m}$ in thickness), the Baka Formation (equivalent to the Middle Siwalik, $2740 \mathrm{~m}$ ), and the Kuine and Panikhola Gaun Formation (equivalent to the Upper Siwalik, $1500 \mathrm{~m}$ ), in ascending order (Fig. 2). The Chisapani Formation is composed of red mudstones and fine- to mediumgrained sandstones, and is subdivided into lower, middle, and upper members. The Baka Formation is composed of medium- to coarse-grained sandstones, pebbly sandstones, and interbedded greenish-grey mudstones; it is also subdivided into lower, middle, and upper members. The Kuine Formation consists of clast-supported and imbricated pebble to cobble conglomerates, whereas the Panikhola Gaun Formation consists of thick matrix-supported pebble, cobble, and boulder conglomerates.

\section{METHODS}

The facies were identified based on lithofacies, bounding surfaces, internal sedimentary structures, and textures, together with the paleocurrent directions. Paleocurrent directions were determined by measuring the inclination of cross-stratifications, ripples, and flute casts, along with flow axis from parting lineation. Existing paleomagnetic age data (Gautam and Fujiwara 2000) used for age of individual facies associations. Although the specific age of the upper boundary of the middle Siwalik has not yet been obtained in the Karnali River section, it is expected to be around 3.9 Ma, based on calculated sedimentation rate (Gautam and Fujiwara 2000).

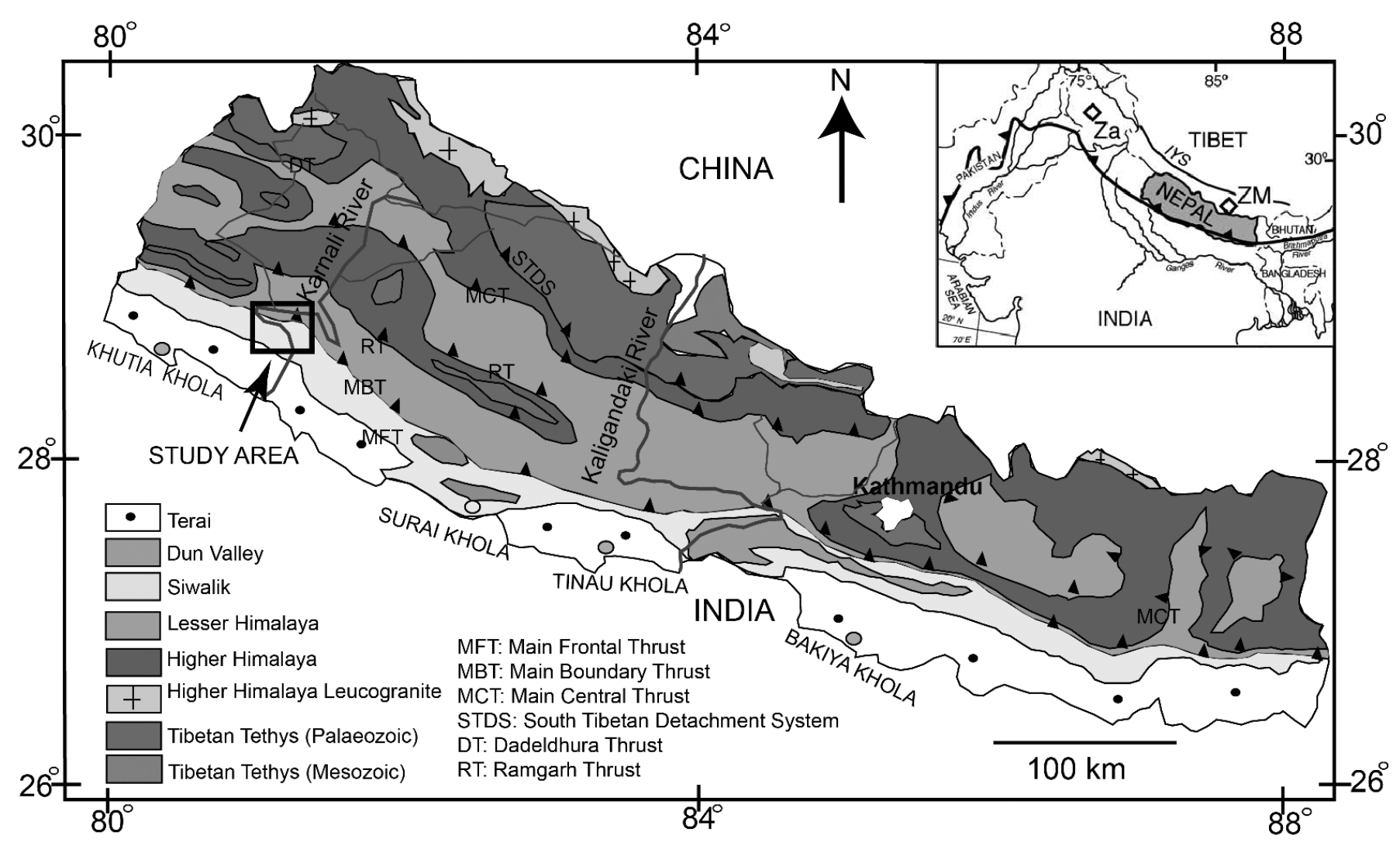

Fig. 1: Generalized geological map of Nepal Himalaya (modified from Amatya and Jnawali 1994). Open rectangle indicates the location of the study area. 


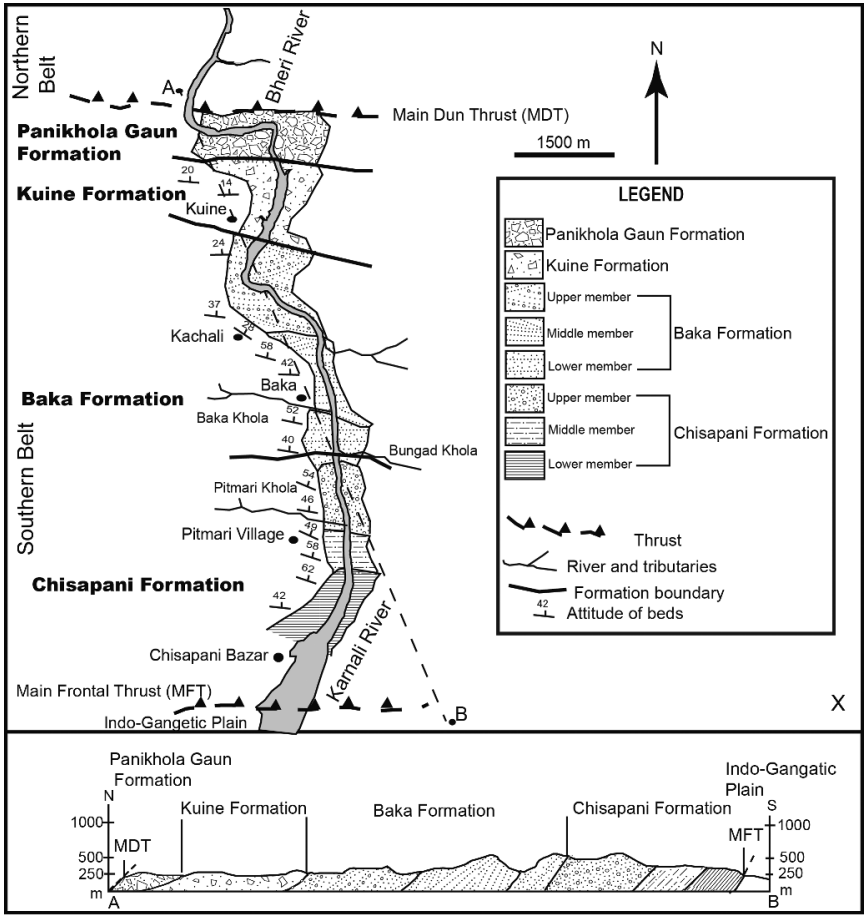

Fig. 2: Geological division of the Siwalik Group along the Karnali River section (Sigdel et al. 2011).
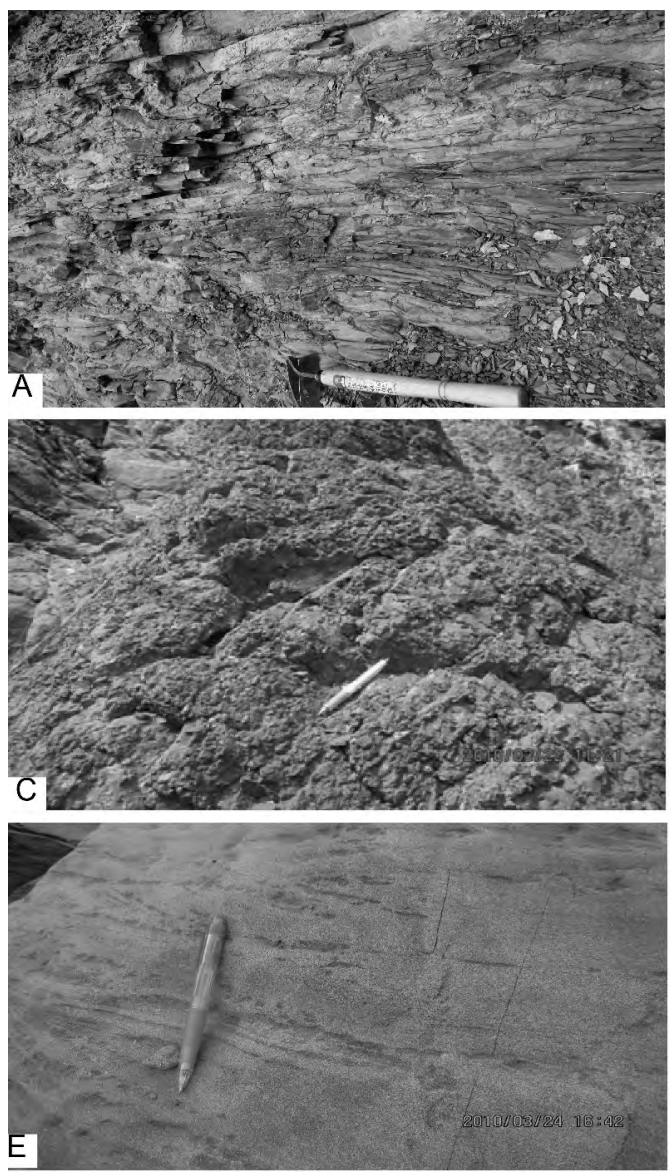

\section{LITHOFACIES}

Twelve sedimentary lithofacies were identified in the four formations and are included into the mudstone, sandstone and conglomerate facies sub-chapters. The lithofacies codes of Miall (1996) were used in this study (Table 1, Fig. 3, 4).

\section{Mudstone facies}

The mudstone facies consist of facies Fl, Fm, and P (Fig. $3 \mathrm{~A}, \mathrm{~B}, \mathrm{C})$. The $\mathrm{Fl}$ mudstones are mainly grey, and contain parallel lamination. The thickness of this facies ranges from $0.5-1 \mathrm{~m}$. The Fm facies is generally massive, but contains some desiccation cracks, rain drop imprints, bioturbation, and nodules or concretions. Individual beds range in thickness from 0.5 to $2 \mathrm{~m}$. The Paleosols (P) facies is mainly reddish-brown to greenish-brown, and contains nodules and concretions, roots, burrows, and slickensides. Pedogenic carbonate is usually nodular, but is also present in pedotubule forms. Bed thicknesses range from 3 to $5 \mathrm{~m}$.

\section{Sandstone facies}

The sandstone facies (St) consists of medium- to coarsegrained, moderately to poorly-sorted, trough cross-stratified
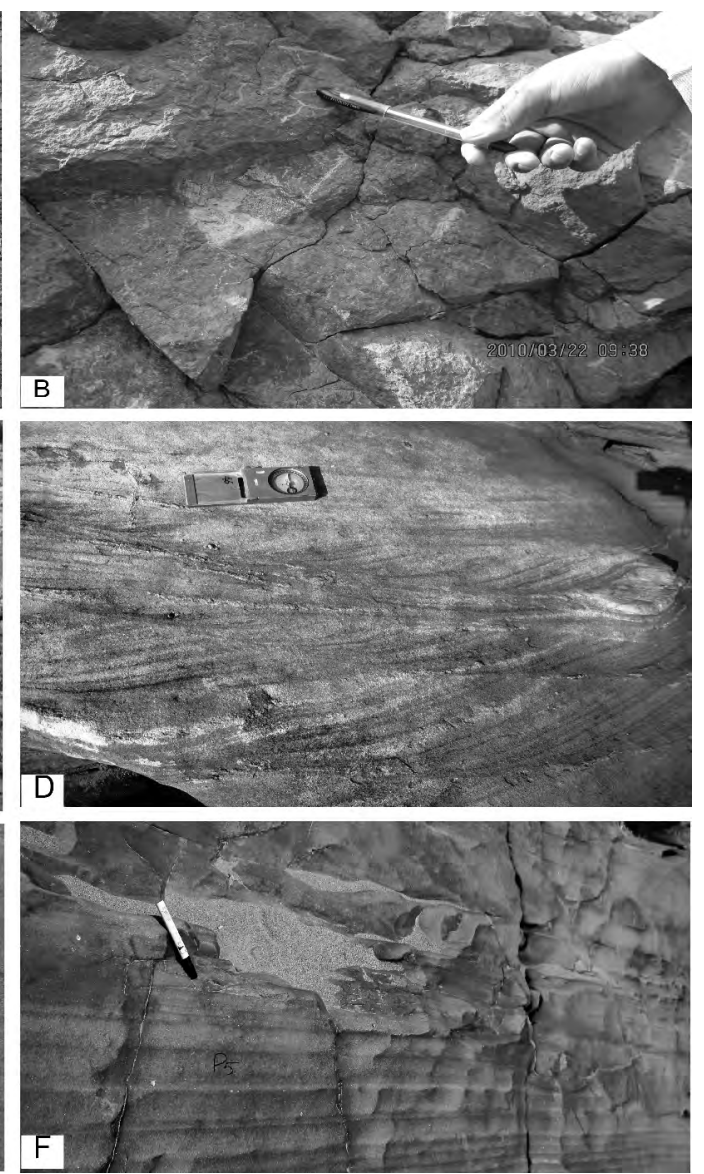

Fig. 3: Outcrop photographs of the lithofacies, A. Laminated mudstone (FI), B. Massive mudstone with some roots $(\mathrm{Fm}), \mathrm{C}$. Reddish-brown paleosols $(\mathrm{P})$, D. Coarse-grained trough cross-stratified sandstone (St), E. Planar cross-laminated sandstone (Sp), F. Parallel laminated sandstone (Sh). 
Table 1: Description and interpretation of the depositional facies (after Miall 1996).

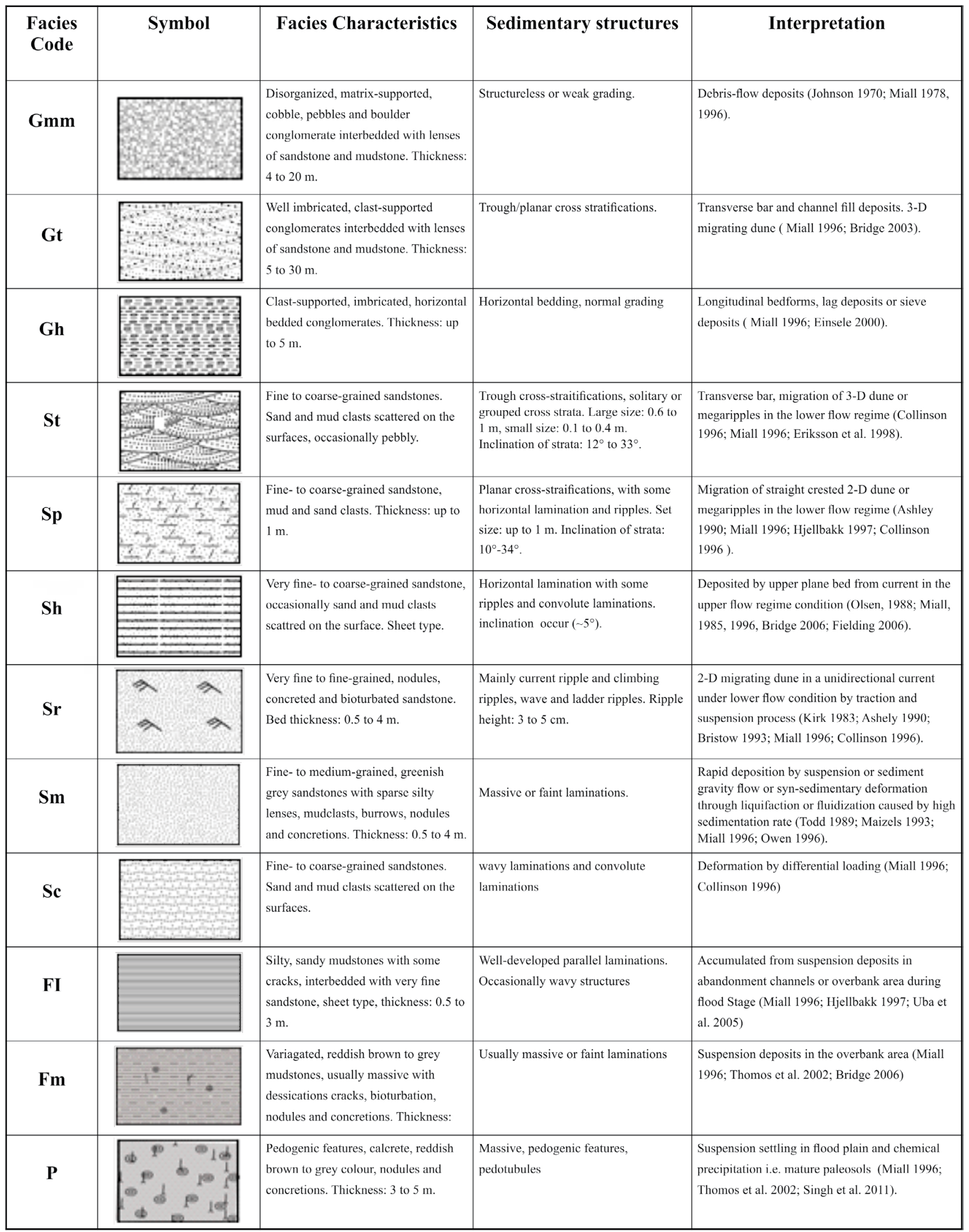



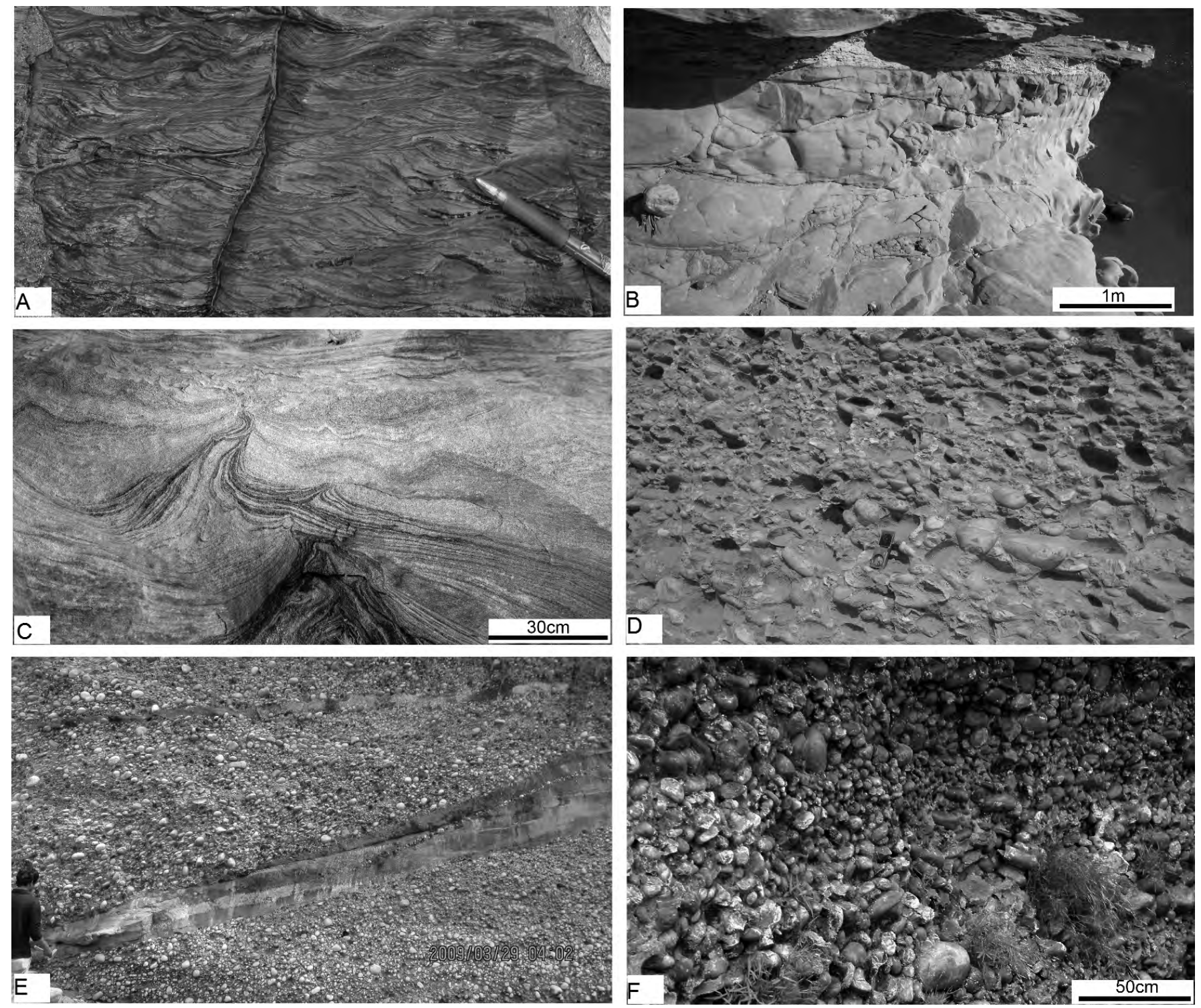

Fig. 4: Outcrop photographs of the lithofacies, A. Rippled laminated sandstone (Sr), B. Massive sandstone (Sm), C. Convolute laminated sandstone (Sc), D. Matrix-supported, poorly-sorted boulder conglomerate (Gmm), E. Clastsupported, well-sorted conglomerate (Gt), F. Normally-graded pebble to cobble conglomerate (Gh).

sandstones (Fig. 3D). The largest troughs are $0.6 \mathrm{~m}$ thick and 1.8 $\mathrm{m}$ wide, although some small types ( $0.1 \mathrm{~m}$ thick to $0.4 \mathrm{~m}$ wide) also occur. The $\mathrm{Sp}$ facies consists of fine- to coarse-grained, planar cross-stratified sandstones (Fig. 3E), in sets up to $1 \mathrm{~m}$ thick. Thicknesses of the planar cross-strata typically decrease with decreasing grain size. The Sh facies is represented by very fine- to coarse-grained, parallel laminated sandstones (Fig. 3F). Parallel laminations are slightly inclined $\left(\sim 5^{\circ}\right)$ in some cases. Facies Sr consists of very fine- to fine-grained sandstones with both current and climbing ripples (Fig. 4A). Thickness of this facies ranges from 0.5 to $4 \mathrm{~m}$. In some cases, ladder ripples are also found in fine-grained sandstones. Facies Sm is composed of greenish-grey to grey, fine- to medium-grained sandstones (Fig. 4B). This sandstone facies contains abundant nodules, concretions and bioturbation. Thickness of this facies ranges from $0.5 \mathrm{~m}$ to $4 \mathrm{~m}$. Facies $\mathrm{Sc}$ is generally found in the medium- to coarse-grained sandstones (Fig. 4C).

\section{Conglomerate facies}

The main conglomerate facies consists of stratified, poorlysorted, matrix-supported boulder conglomerates (Gmm). The matrix is generally poorly-sorted sand. The length of clasts (a-axis) is up to 0.2 to $0.3 \mathrm{~m}$. Gmm conglomerate beds range from 4 to $20 \mathrm{~m}$ in thickness (Fig. 4D). The other facies present include well-sorted, imbricated, clast-supported trough or planar cross-stratified conglomerates (Gt), and horizontallystratified, normally-graded conglomerates (Gh) (Fig. 4E, F). Thicknesses of the sets of Gt bed range from 5 to $30 \mathrm{~m}$. The pebbles are generally elliptical to tabular, and long axes reach 8 $\mathrm{cm}$. The Gh facies consists of generally well-sorted, normallygraded conglomerates, with thicknesses of up to $5 \mathrm{~m}$. 


\section{FACIES ASSOCIATIONS}

Six facies associations have been recognized on the basis of individual facies, architectural elements and bed geometry. Huyghe et al. (2005) analyzed facies association, we have further refined the classification based on bed-by-bed description.

\section{Facies association (FA1)}

Facies association FA1 is dominated by the mudstone facies Fm, Fl, and P, along with subordinate sandstone facies Sr, St, Sp and Sh (Fig. 5). This association corresponds to the KFA1 facies association of Huyghe et al. (2005). This facies association is found in the lower member of the Chisapani Formation, and in the lower half of its middle member. The thickness of this FA is about $770 \mathrm{~m}$ (Fig. 14). FA1 consists of piles of fining-upward sediment successions. Thicknesses of the individual successions range from 1 to $5 \mathrm{~m}$ in the lower member, but reach up to $12 \mathrm{~m}$ in the middle member. The bases of the successions are flat, or are represented by shallow irregular depressions with relief of up to $0.5 \mathrm{~m}$. From base to the top, the succession consists of facies $\mathrm{St}, \mathrm{Sp}, \mathrm{Sh}$, and $\mathrm{Sr}$, grading into facies Fm, Fl and P. Facies Sh appears at the base of some successions (Fig. 5A). The successions show well developed lateral accretion patterns in their basal parts (Fig. 6A). Paleocurrent directions are measured from plannar, trough cross stratification and ripples laminations $(n=86)$ which show highly dispersed, ranging from southeast to northwest (azimuth, $162^{\circ}$ to $308^{\circ}$ ) (Fig. 5 locs C, D). Although Szulc et al. (2006) also measured the paleoflow $(n=15)$ direction from this facies association which shows low dispersion. The low dispersion of paleoflow is due to lack of sufficient data (measured only from upper part of this facies association and ignored the lower part) or they measured from limited exposures. The lateral accretion direction is also highly variable, and is directed northwest on average. Mudstone beds (Fl) overlie the individual successions. These mudstones have sheet-like pattern, and show vertical accretion in the lower half of this facies association (Fig. 6B). The reddish-brown facies (red mudstone, $\mathrm{P}$ ) is well developed in the upper half of FA1 (Fig. 6C, D). Facies Sp and Sr beds are interbedded with mudstone intervals (Fl, Fm) at some locations; these pinch out laterally over widths of 10 to $50 \mathrm{~m}$. The lower half of the facies association FA1 is dominated by mudstone facies, and becomes sandier upward.

\section{Interpretation (FA1)}

The fining-upward sediment successions with lateral accretion pattern are typical characteristics of point bar deposits of meandering river (Miall 1996; Peakall et al. 2007). The highly dispersed paleocurrent and lateral accretion directions suggest that the channels are highly sinuous. The lenticular shape of interbedded planar cross-stratified sandstones (facies $\mathrm{Sp}$ ) in the mudstone beds ( $\mathrm{Fl})$ is typical of crevasse splay deposits (cf. Olsen 1986; Miall 1996). Mudstone facies (Fm and $\mathrm{P}$ ) are interpreted as flood plain deposits. Alternation of thin sheet mudstones and sandstones with ripples laminations is evidence for deposition from suspension under calm water conditions (Hjellbakk 1997). The predominance of reddishbrown soils (P) indicates seasonal dry and wet climatic conditions (Retallack 1991; Khadkikar et al. 1999). The sandier-upward trend may represent a shift of the depocenter from distal to proximal part of the depositional basin. The point bar deposits with abundant fine-grained facies (muddominated) are consistent with the characteristics of a finegrained meandering river system (Miall 1996; Nakayama and Ulak 1999).

\section{Facies association (FA2)}

Facies association FA2 is dominated by the sandstone facies St, Sp, Sr, Sh with subordinate facies Fl, Fm and P. This facies association appears in the uppermost part of the middle member of the Chisapani Formation and in its upper member, and contains piles of fining-upward successions (Fig. 5). The thickness of this FA is about $1275 \mathrm{~m}$. The bases of these successions are represented by erosion surfaces, and the basal parts contain intraformational mud clasts. From the base to top, the successions consist of facies St, Sp, Sh and $\mathrm{Sr}$, grading into muddy facies Fm and Fl. Thicknesses of the individual fining-upward successions range from 1 to $15 \mathrm{~m}$. The sandstone parts of these successions show well-developed lateral accretion patterns (Fig. 5 locs. H, I, and Fig. 7A), with paleocurrent directions dispersed from southeast to southwest (azimuth, $142^{\circ}$ to $249^{\circ}$ ) (Fig. 5). The mudstone facies ( $\mathrm{Fl}$, Fm, and P) are greenish-grey to grey, thinly-bedded, and are intercalated with thinly laminated, rippled or climbing rippled sandstones, showing sheet-like geometry as a whole (Fig. 7B, C). Total thickness of these thin-bedded sheet sandstones may reach $2 \mathrm{~m}$. The frequency of these sheet-type beds tends to increase toward the upper member of the Chisapani Formation. This set is similar to the sheet-splay deposits reported from other Siwalik sections (Hisatomi and Tanaka 1994). FA2 also contains alternations of laminated mudstones (Fl), mud flake layers, and thin very fine-grained sandstone layers (Sh) or (Sm) (Fig. 7D). The Fl layers are $2-10 \mathrm{~cm}$ thick and are partly disrupted by desiccation cracks and root traces (Fig. 8A, B, $\mathrm{C}, \mathrm{D})$. The mud flakes are $2-5 \mathrm{~mm}$ in diameter. The sandstone layers $(\mathrm{Sh})$ or $(\mathrm{Sm})$ are up to $20 \mathrm{~cm}$ thick. The overall thickness of these alternations may reach $1.5 \mathrm{~m}$ (Fig. 8).

\section{Interpretation (FA2)}

The characteristics of the sandstones show that the channel features are similar to those in FA1. The dispersal patterns of the paleocurrents suggest that the channel was slightly sinuous. Alternations of thin sheet-like sandstones (Sh, Sr) and mudstone beds (Fl) are interpreted as flood plain deposits (Hisatomi and Tanaka 1994; Miall 1996, Nakayama and Ulak 1999). Repeated occurrences of thin layers of sandstone (Sh and Sr) beds within facies Fl and Fm are formed by increased frequency of floods (c.f. Nakayama and Ulak 1999). The paleosols facies indicate highly seasonal climate with increased rainfall (Retallack 1991; Tanaka 1997). Alternations of thin laminated mudstones, mud flake layers and fine-grained 


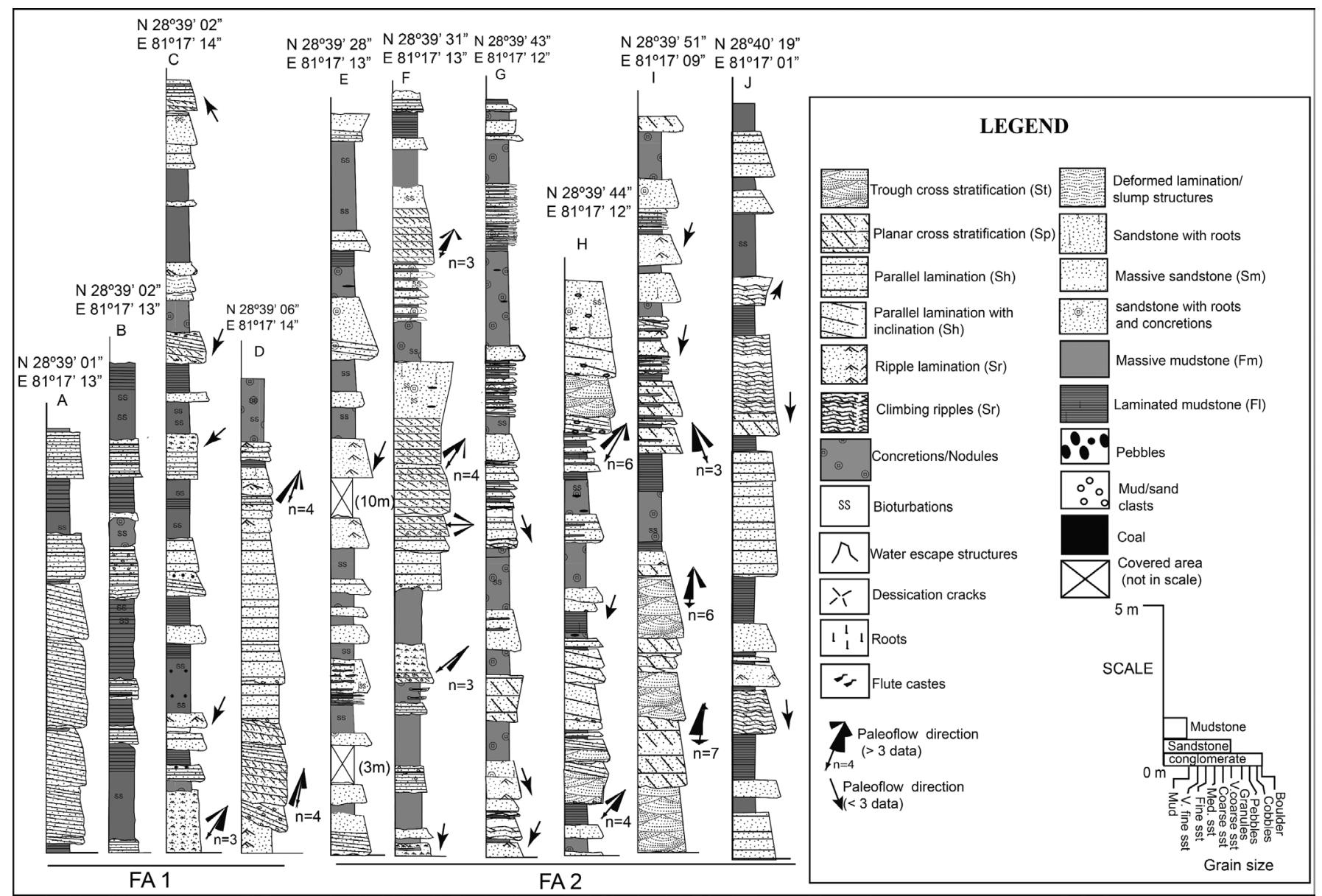

Fig. 5: Detailed representative columnar sections of facies associations FA1 and FA2, showing vertical relationship of the facies. Letters A, B, C... J (with latitude and longitude) at the top of each column indicates the location of the sections.

Fig. 6: Outcrop of the facies association FA1, A. Typical example of the lateral accretion pattern. The black line indicates the bedding plane and red lines indicate the traces of the accretion units in sandstone. The hammer is $30 \mathrm{~cm}$ long, B. Laminated grey mudstones with roots traces and bioturbation, interpreted as flood plain deposits. The scale is $50 \mathrm{~cm}$ long, C. Outcrops of the red mudstone in the upper part of the FA1. The outcrop is $10 \mathrm{~m}$ high, D. Detail of red soil beds containing nodules, concretions and bioturbation indicative of drier climate. The scale is $15 \mathrm{~cm}$ long.
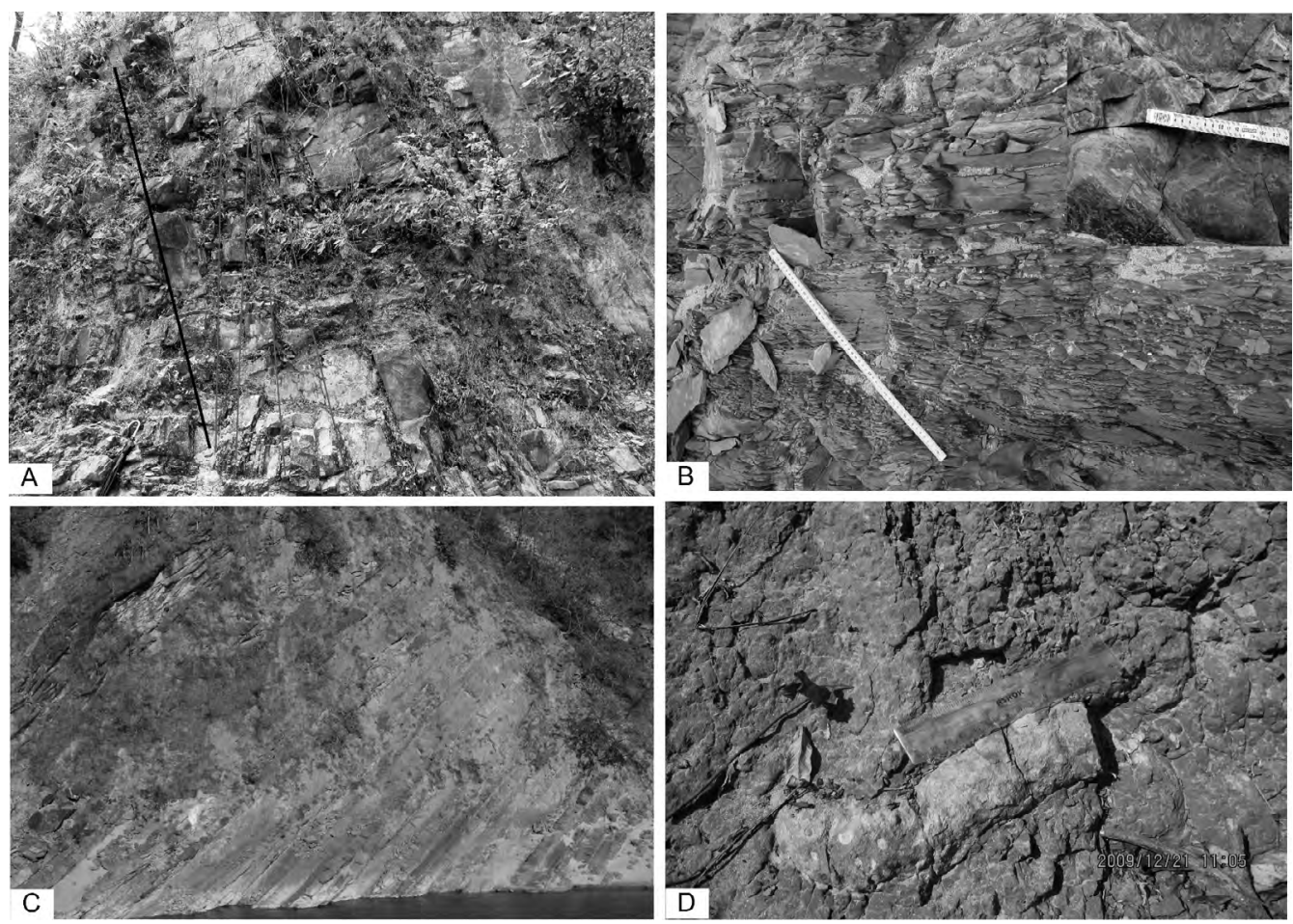
Fig. 7: Outcrop photographs of facies association FA2, A. Example of the lateral accretion pattern. The outcrop is $10 \mathrm{~m}$ thick. The black line indicates the bedding plane, and red dot lines indicate the traces of the accretion units in sandstone, B. Alternations of thin sandstone (FI) and mudstone (FI) with sheet type geometry, interpreted as flood plain deposits. The outcrop is $20 \mathrm{~m}$ high, $C$. Alternation of climbing ripples and parallel laminated sandstones representing flood flow deposits. $30 \mathrm{~cm}$ hammer for scale, D. Detail of grey laminated soil beds indicating water logged conditions. $30 \mathrm{~cm}$ hammer for scale.
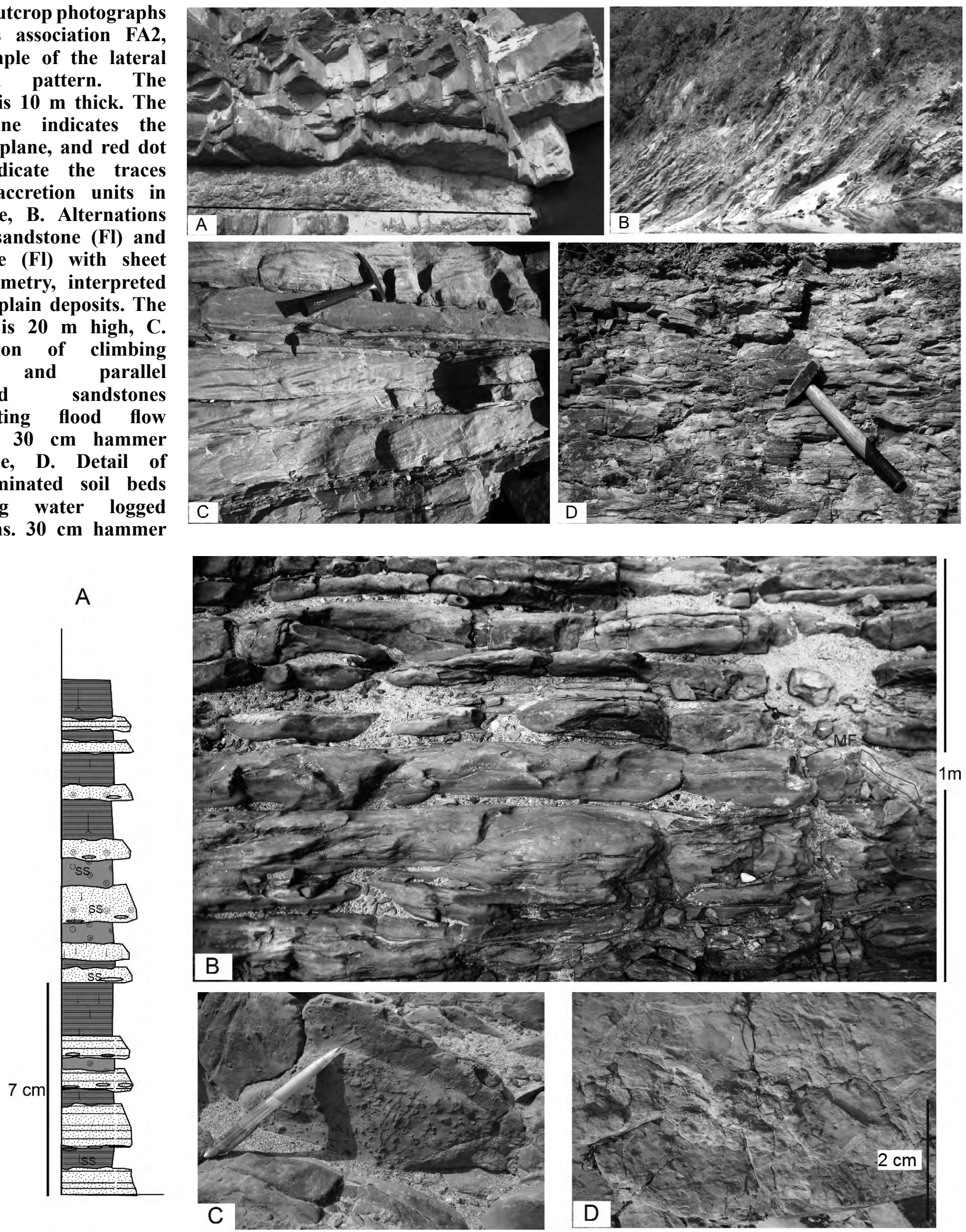

Fig. 8: Outcrop photographs of the playa lake facies in facies association FA2, A. Simplified columnar section shows laminated mudstone beds with roots and bioturbation, mud flake layers, and laminated, massive very fine-grained sandstone beds, suggesting repeated drying and inundation of a playa lake. Legend as in Fig. 4, B. The bed at outcrop. Arrows indicate the laminated mudstone, dark color indicates the very fine grained sandstone and red ellipses indicate mud flake layer, $C$. Roots traces in the laminated mudstone beds. $15 \mathrm{~cm}$ pen for scale, D. Desiccation cracks developed in the mudstone beds. 
massive sandstone layers are interpreted as repetitions of dryup and inundation of ephemeral lakes (Bordy and Catuneanu 2001; Hampton and Horton 2007; Bourquin et al. 2009; Sakai et al. 2010). The repeated occurrence of such laterally accreted channel sandstones with abundant sheet-type flood plain facies and ephemeral lake facies indicates that facies association FA2 was deposited by a flood-flow dominated meandering river system during seasonal climate. This facies association corresponds to KFA2 and KFA3 of the Huyghe et al. (2005) classification, but the lower and upper limits of this FA differ because of the presence of intermittently appeared braided river facies in the lower and upper parts with age discrepancy. The characteristics of this facies association are also similar to the FA2 and FA3 facies associations of Nakayama and Ulak (1999) from other Siwalik sections.

\section{Facies association (FA3)}

Facies association FA3 consists predominately of sandstone facies St, Sp, Sh, Sr, Sc and Sm, with Fl and Fm facies as minor components (Fig. 9). This association belongs to the KFA4 facies association of Huyghe et al. (2005), and appears in the lower and middle members of the Baka Formation. The thickness of this FA is about $1190 \mathrm{~m}$. FA3 contains several sets of sandstone successions, and each of these sets contain fining-upward successions (Fig. 9, 10A). The fining-upward successions contain facies St covering the erosional surface, succeeded by facies $\mathrm{Sp}, \mathrm{Sh}, \mathrm{Sr}$ and $\mathrm{Sm}$ in ascending order, and then grading into the muddy facies Fm and Fl. Thickness of the individual fining-upward successions reaches $20 \mathrm{~m}$. Compound cross-strata are evident (sets of large scale inclined strata, Bridge 2003) (Fig. 9, 10B), occupying the lower and middle parts of the fining-upward successions. These inclined strata are commonly discontinuous. The large scale strata are commonly composed of small scale sets of $\mathrm{St}$ and $\mathrm{Sp}$ or $\mathrm{Sr}$, and show fining-upward grain size trend (1-4 m). These cross stratifications are commonly discordant. First and second order surfaces (Miall 1985) separate these sets (Fig. 10B, C). Paleocurrent directions are predominantly towards the southwest (mean azimuth $193^{\circ}$ ) (Fig 9), and dip directions of these set boundaries are similar to that of the cross stratification i.e. toward southeast to southwest. In some cases, coarseningupward successions also occur. These sandstones contain facies $\mathrm{Sh}$ and $\mathrm{Sp}$ at their base, massive facies $\mathrm{Sm}$ with bioturbation and concretions at their top, and show coarsening-upward trend or little variation in grain size. Thicknesses of these sandstone beds reach $7 \mathrm{~m}$. This type of facies occurs intermittently in the lower part of facies association FA2 (Fig. 5, loc. F). The greenish-grey $\mathrm{Sm}$ sandstone facies and Fm or Fl mudstone facies cap the upper part of the fining-upward successions (Fig. 9 locs L, M). Individual sandstone successions are separated by alternations of sheet-type fine- to medium- grained sandstone facies $\mathrm{Sr}$ and $\mathrm{Sh}$ and mudstone facies Fl and Fm (Fig. 10D). Thickness of these alternations ranges from 0.2 to $2 \mathrm{~m}$.

\section{Interpretation (FA3)}

The large inclined cross-stratification with compound sets of facies St, Sp within individual fining-upward successions is interpreted as downstream accretion (Smith 1972; Allen 1983; Bristow 1993; Miall 1996; Bridge 2003; Lunt et al. 2004). Low unimodal paleocurrent dispersion and dominance of downstream accretion patterns suggest braided channel deposits (Allen 1983). Thick fining-upward successions correspond to channel depth, which reached $20 \mathrm{~m}$. Discontinuous appearance of these strata may be associated with the occurrence of side bars or transitions from lower to upper bar deposits (Bridge and Tye 2000; Bridge 2006). Discordances in cross strata may have formed by lateral shift in channel position, and may be related to formation of mid channel bars (Bridge 2006). The fining-upward trend of sets of $\mathrm{St}$ and $\mathrm{Sp}$ or $\mathrm{Sr}$ facies within the large inclined strata represent episodic discharge fluctuation (Godin 1991; Bridge and Tye 2000). Coarsening-upward successions also present if only upstream parts of braided bars (Bridge 2006) or ephemeral braided stream facies are preserved (Bhattacharya and Morad 1993). The Sm facies in the upper part of the succession is formed by rapid sediment deposition from mass flows, triggered by falling water level after flooding (Maizels 1993; Martin and Turner 1998). The muddy facies (Fm and $\mathrm{Fl}$ ) overlying the individual finingupward successions suggests deposition by waning flood on subaerial exposed bar tops (Miall 1996). The alternations of the fine-grained, thinly bedded, sheet-type sandstone facies $\mathrm{Sr}$, Sh and Fl, Fm represent abandoned channel or flood plain deposits. Facies association FA3 are similar with the deep sandy braided river system (FA4) described from other Siwalik successions (Nakayama and Ulak 1999).

\section{Facies association (FA4)}

This facies association is dominated by pebbly, coarse- to very coarse-grained, sandstones (facies St, Sp, Sh and Sr), with facies $\mathrm{Fl}$ and $\mathrm{Fm}$ as a minor component (Fig. 9). FA4 is found in the upper member of the Baka Formation, and corresponds to the KFA5 and KFA6 facies associations of Huyghe et al. (2005). Total thickness of this facies association is about $1550 \mathrm{~m}$. Individual sandstone successions show sheet-type geometry. Each succession is marked by a laterally continuous basal erosional surface, and faint fining-upward trend (Fig. 9 loc N, O). Thicknesses of individual fining-upward successions reach $7 \mathrm{~m}$. Individual sheet boundaries also contain frequent erosional surfaces and associated mud/sand clasts (Fig. 11A). Facies Sp and Sh appear in the basal part of the successions, and the beds show concave-up geometry (Fig. 9, locs. N, O, P). Facies St beds containing abundant pebbles and sand/mud clasts cover the erosional base of the successions at some sites (Fig. 11A, B). Paleocurrent directions are dominantly towards the southeast (Fig. 9, locs. N, O, P). The proportion of mudstone facies $\mathrm{Fl}$ and $\mathrm{Fm}$ is much lower than the sandstone facies, forming the uppermost part of the successions (Fig. 11C). The mudstone facies ranges from 0.5 to $2 \mathrm{~m}$ in thickness. 


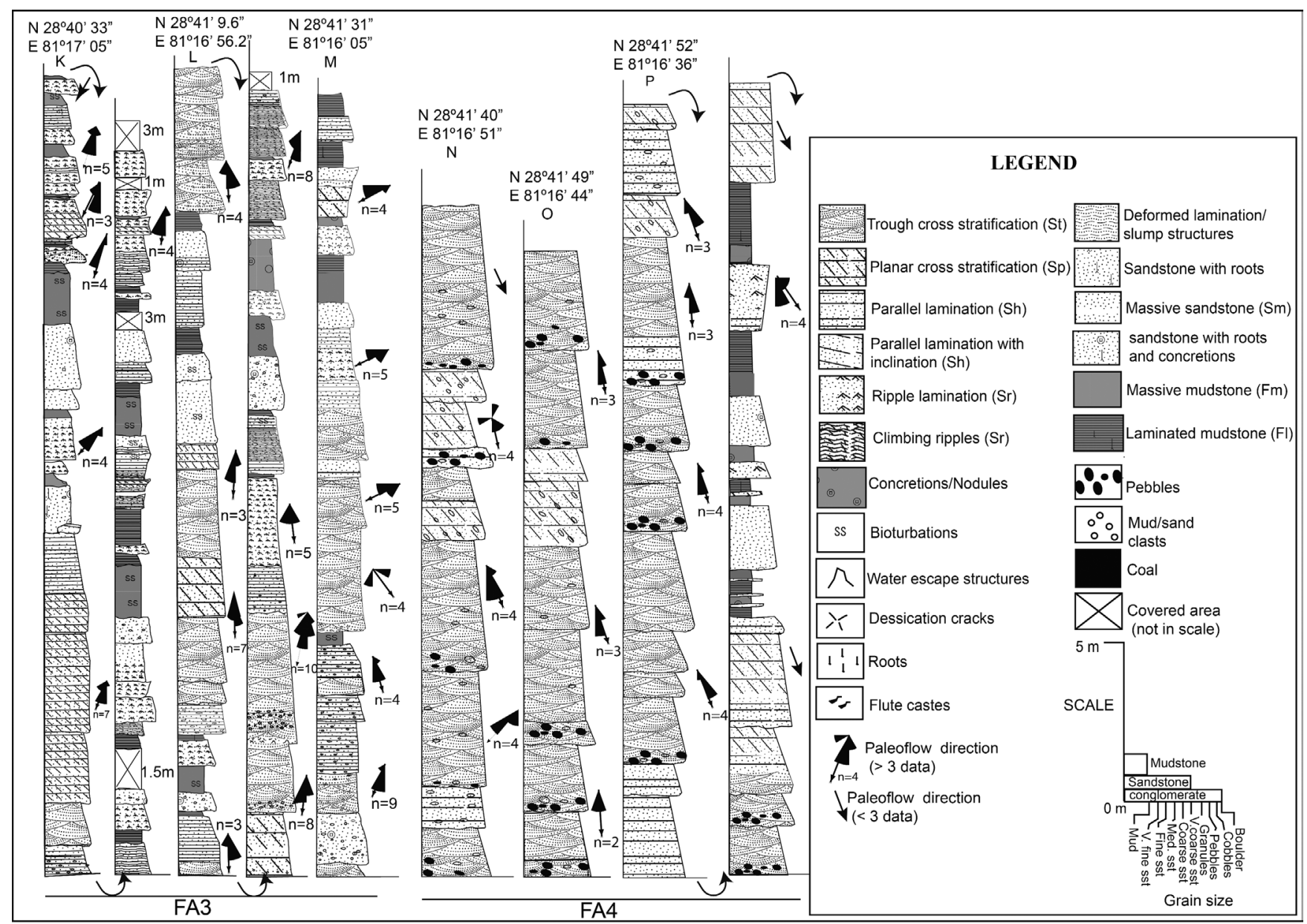

Fig. 9: Detailed representative columnar sections of facies associations FA3 and FA4. Letters K, L, M, N, P (with latitude and longitude) at the top of each column indicate the location of the sections.

\section{Interpretation (FA4)}

The faint fining-upward St and Sp facies successions and frequent erosional surfaces containing abundant sand/mud clasts indicate periodic reworking of fine-grained sediments due to lateral migration of bars within the channels (Kumar and Nanda, 1989; Miall, 1977). The laterally continuous sand sheets dominated by large scale facies Sp and St reflect the migration of dunes in high energy conditions. The unimodal paleoflow direction and low proportion of facies Fm and Fl suggest that the bedforms observed were generated during migration of compound bars in relatively shallow channels of a braided river (Smith, 1972; Miall, 1978, 1996; Roe and Hermansen, 1993). Thicknesses of the individual finingupward successions suggest the channels were shallower than those in facies association FA3. Presence of abundant pebbles indicate that the site of deposition was more proximal to the hinterland. This facies association is interpreted as the deposits of a shallow and sandy braided river system (Miall, 1996). This facies association corresponds to the shallow sandy braided river of Nakayama and Ulak (1999).

\section{Facies association (FA5)}

This facies association is dominated by gravel facies Gt and Gh (Fig. 12A, B, C). The sandy and muddy facies St, Sp and
Fm occur as minor components. FA5 is found in the Kuine Formation, and corresponds to the KFA7 facies association of Huyghe et al. (2005) and FA7 facies association of Nakayama and Ulak, (1999). The thickness of this interval is about 1000 $\mathrm{m}$. The Gt beds are generally gently inclined, and individual beds are overlain by facies St, and Sp at their top (Fig. 12A, B). Each inclined bed has an undulatory base and top, and thickness varies from 1 to $2 \mathrm{~m}$. Facies Gh appears in place of $\mathrm{Gt}$ at some locations. Facies St, $\mathrm{Sr}$ and $\mathrm{Fm}$ are lenticular in shape, and reach thickness of $1 \mathrm{~m}$ (Fig. 12B).

\section{Interpretation (FA5)}

Facies Gt and Gh contain imbricated gravels, suggesting deposition from a high energy river system equivalent to gravel-laden braided streams (Maizel 1989; Brierley et al. 1993; Bridge 2006). The gravels were generally transported as bedload, and were deposited under waning flow by progressive accretion of smaller clasts, in channels as lag deposits, and on longitudinal bars of a gravelly braided river (Collinson 1986; Rust 1984; Miall 1990; Bridge 2006). The variation in bed thickness is related to the periodic growth and migration of bars, and their subsequent erosion (Pandita et al. 2011). Facies $\mathrm{St}$ and $\mathrm{Sp}$ suggest the winnowing of fine sediments during waning flow toward the bar margin (Miall 1996). This facies 

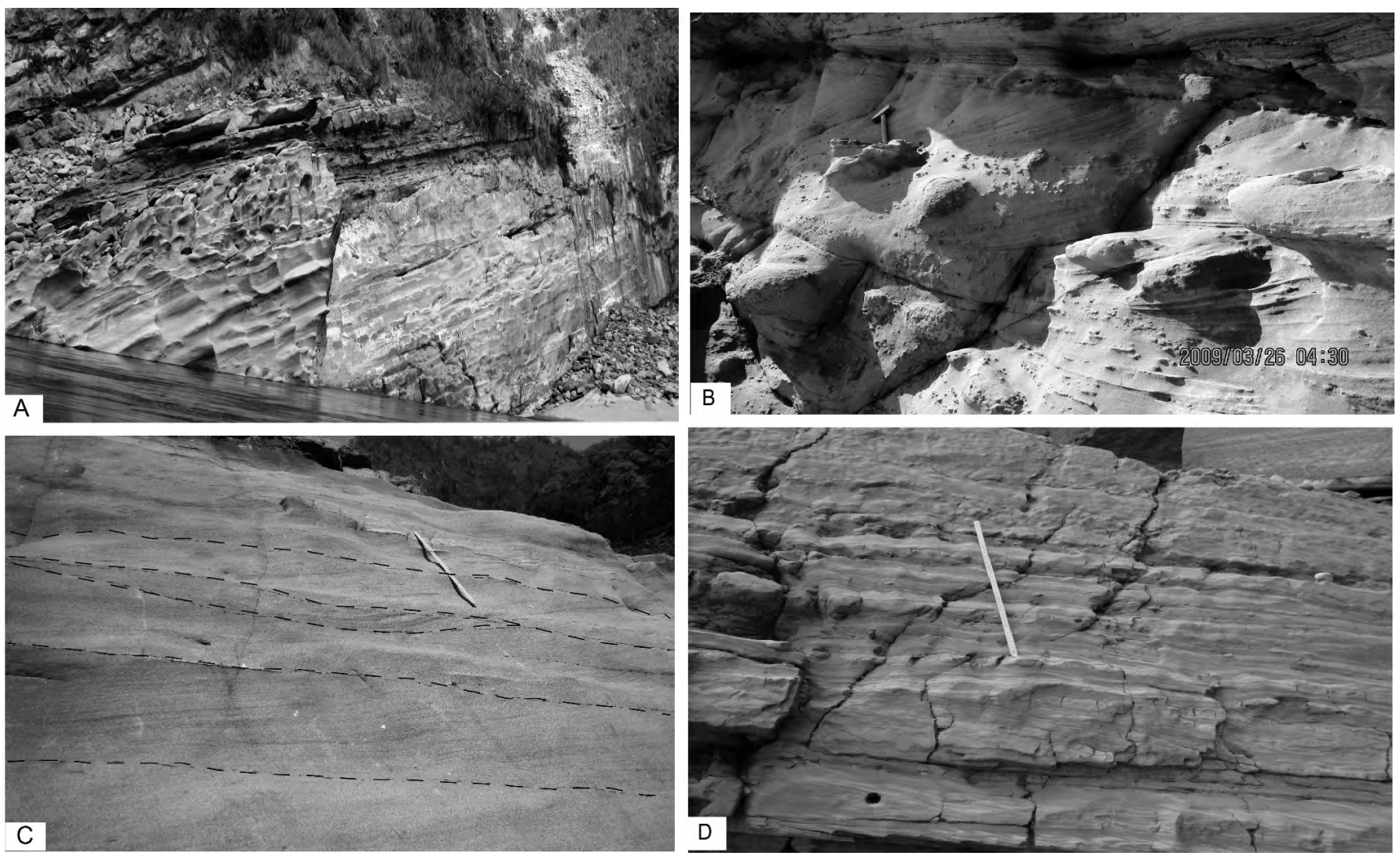

Fig. 10: Outcrop photographs of facies association FA 3, A. Coarse-grained, amalgamated, sheet sandstones of the braided river deposits. The outcrop is $10 \mathrm{~m}$ high, B. Trough cross-bedded sandstone indicating downstream accretion. $30 \mathrm{~cm}$ hammer for scale, $C$. Large scale trough cross-stratification with several bounding surfaces showing migration of braided bars. The scale is $75 \mathrm{~cm}$, D. Parallel lamination and rippled sandstones interpreted as overbank deposits on a flood plain. The scale is $50 \mathrm{~cm}$ long.

association is interpreted as the product of a gravelly braided river system (Miall 1996; Nakayama and Ulak 1999).

\section{Facies association (FA6)}

This facies association is dominated by facies Gmm. Facies Gt, St or Sp or Fm also occur as minor components (Fig. 13). This facies association is found in the Panikhola Gaun Formation, but was not investigated by Huyghe et al. (2005) in this section. The total thickness of this interval is about 500 $\mathrm{m}$. Facies $\mathrm{Gmm}$ is characterized by massive, generally poorlysorted, matrix-supported conglomerate beds with disorganized grain fabric (Fig. 13A). Thickness of the massive bed sets ranges from 4 to $20 \mathrm{~m}$. Clast-supported conglomerate beds (Gt) are locally interbedded between the matrix-supported Gmm facies (Fig. 13B). The boundaries between Gmm and Gt are slightly undulatory or flat. In places, facies St, Sp or Fm appear as lens between Gmm beds.

\section{Interpretation (FA6)}

The poor sorting of the $\mathrm{Gmm}$ beds and absence of stratification suggest that this facies was deposited from debris flows (e.g. Johnson 1970; Blair and McPherson 1998; Miall 1985, 1996). The Gt beds and lenticular facies St, Sp or Fm beds are interpreted as stream-flow deposits, truncating the debris-flow deposits (Hartley 1993). This facies association corresponds to the debris-flow dominated braided river system (FA8) identified in other Siwalik sections (Nakayama and Ulak 1999).

\section{DISCUSSION}

\section{Comparison with previous work}

The facies analysis and paleocurrent data show that Siwalik Group sediments along the Karnali River section were deposited from a fine-grained meandering river system (15.813.5 Ma), a flood-flow dominated meandering river system with intermittent appearance of a sandy braided river system (13.5-9.6 Ma), a deep and shallow sandy braided river system (9.6-3.9 Ma), and gravelly braided $(\sim 3.9-\sim 2.0 \mathrm{Ma})$ to debrisflow dominated braided river systems, in ascending order (Fig. 14). This reconstruction differs slightly from the earlier interpretation by Huyghe et al. (2005). The major differences lie in the timing of appearance and characteristics of the floodflow dominated meandering system, and that the anastomosed river system was not identified in this study.

The timing of the appearance of the flood-flow deposit is estimated to be around $13.5 \mathrm{Ma}$, some $0.4 \mathrm{Ma}$ earlier than that suggested by Huyghe et al. (2005). It is believed that the boundary defined here is appropriate, as: i) the appearance of flood-flow dominated system is interpreted to have been 

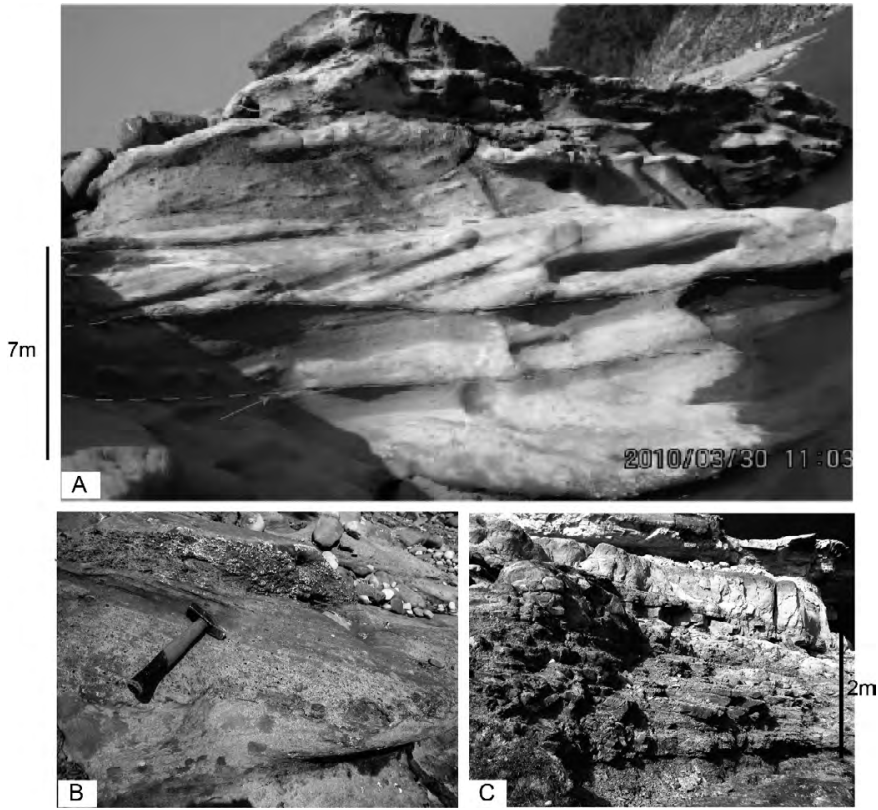
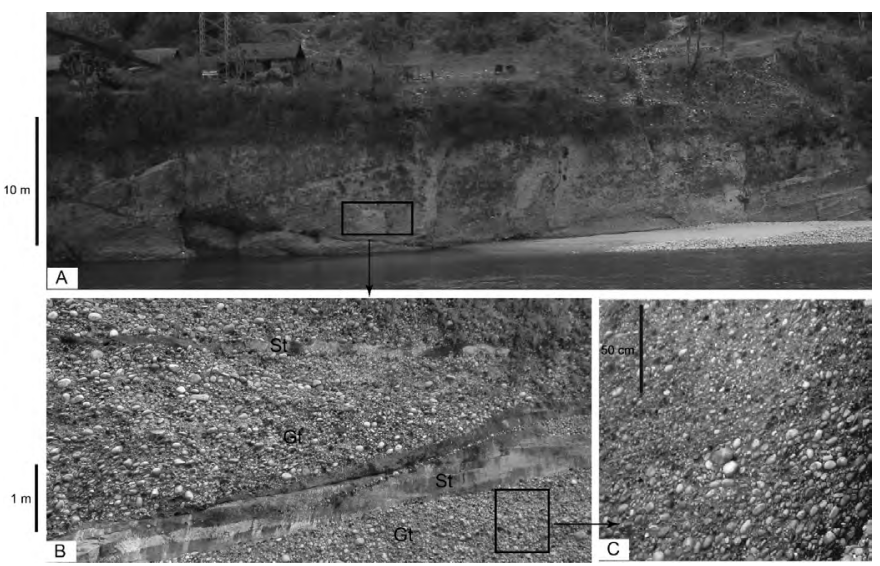

Fig. 12: Outcrop photographs of the facies association FA5, A. Trough cross-bedded conglomerate in a large outcrop. Outcrop is $15 \mathrm{~m}$ high, B. Clast-supported, cobble to pebble conglomerate (Gt) with a lens of sandstone (St). The outcrop is $5 \mathbf{~ m}$ high, C. Close-up of imbricated pebbles.

Fig. 11: Outcrop photographs of the facies association FA4, A. Very coarse-grained sheet sandstone showing trough and planar cross stratifications (Sp, St). The arrow indicates the erosional surface. Total thickness of the outcrop is $15 \mathrm{~m}$, B. Erosional surfaces with pebbles representing shallow river channel. Hammer is $30 \mathrm{~cm}$ long, C. Alternations of sandstone and mudstone in the flood plain.
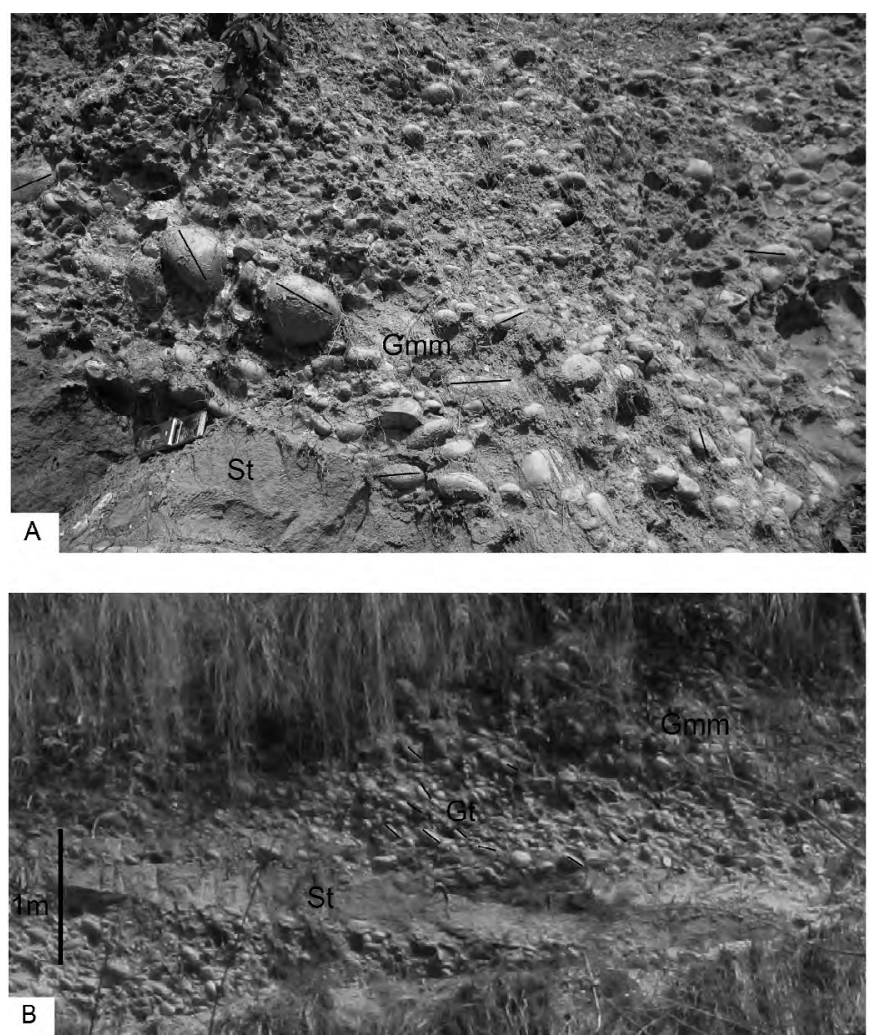

Fig. 13: Outcrop photographs of the facies association FA6, A. Matrix-supported, poorly sorted conglomerate (Gmm) with almost no erosional surface with underlying sandstones (St), typical of debris flow deposits. The compass is $15 \mathrm{~cm}$ long, B. Alternation of lens shaped sandstone and clast-supported conglomerate (Gt) interpreted as stream flow deposits. Outcrop is $3 \mathrm{~m}$ high. associated with an increase in water discharge. Soil colour also changed from reddish-brown to grey or pale greenishgrey, suggesting increased water logging conditions (Retallack 1991), and ii) ephemeral lake deposits were unidentified from FA2, which also suggests more frequent water supply with higher seasonality than in the FA1 phase. We recognized a shallow sandy braided river facies in the interval from which Huyghe et al. (2005) identified an anastomosed river system. This sandy braided river facies is characterized by laterally continuous sheet sandstones dominated by large scale facies $\mathrm{Sp}$ and $\mathrm{St}$ and unimodal paleoflow direction, which indicates the frequent shifting of shallow channels of braided river (Smith 1972; Miall 1996), and the anastomosed river system of Huyghe et al. (2005) is hence interpreted as a braided river system.

\section{Significance of the change from a fine-grained meandering system to a flood-flow dominated meandering system around $13.5 \mathrm{Ma}$}

The change from fine-grained meandering river deposits with red soils (FA1) to the flood flow-dominated meandering river deposits with greenish-grey to yellowish-brown soil (FA2) indicates increased water discharge in the river channel after 13.5 Ma. This increased water discharge arose from increased precipitation related to climate change (Nakayama and Ulak 1999). However, this facies changes is diachronous in Siwalik sections, occurring at around 10.5 Ma, 10.0 Ma and 9.5 Ma in the Bakiya Khola, Tinau Khola, and Surai Khola areas, respectively (Nakayama and Ulak 1999; Ulak and Nakayama 2001) (Fig. 15). Although Huyghe et al. (2005) inferred that larger river catchment size contributed to the earlier appearance of this facies in the Karnali River than in other areas, they provided no specific discussion on the size of the river catchment, or how it affected the fluvial depositional system. 


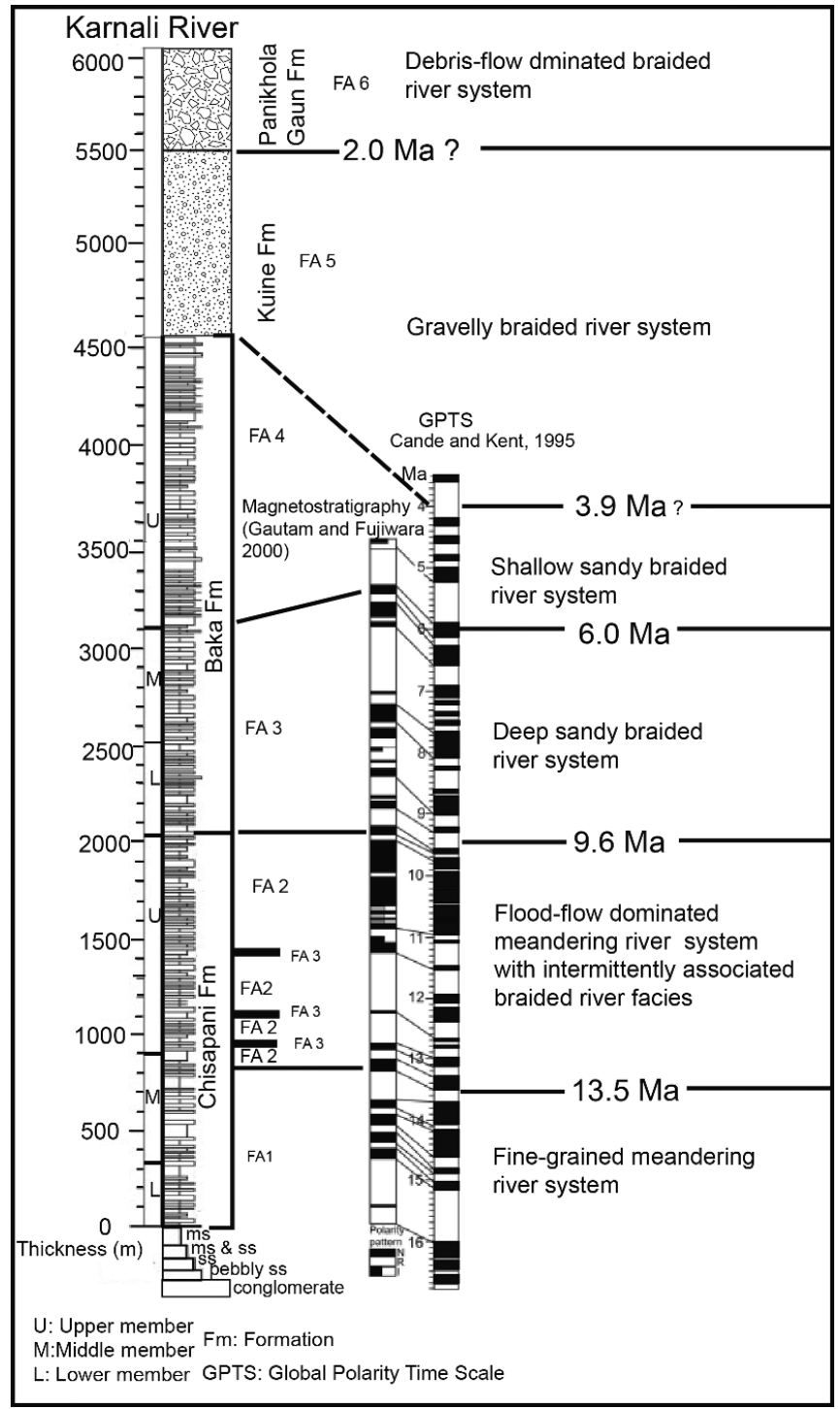

Fig. 14: Classification of the fluvial system in the study area based on the magnetostratigraphic time frame (modified from Gautam and Fujiwara 2000).

River catchment size may be a possible cause of the diachronous facies change, as Huyghe et al. (2005) inferred. Rivers with small catchments size could be strongly affected by orographic precipitation associated with local uplift, as small increases in precipitation can change the channel characteristics. In contrast, if catchments are large, river characteristics (especially width and depth) should respond only to regional precipitation changes, because water supply from their larger area suppresses the effect of local increase or decrease of precipitation on discharge and river channel characteristics.

Presence of large catchment systems in the past has been identified by analysis of river channel deposits and provenance. Such studies in the Tinau Khola section have shown that the sediments were deposited by a larger river system in the past i.e. the paleo-Kaligandaki River (Tokuoka et al. 1986; Hisatomi and Tanaka 1994; Nakayama and Ulak 1999; Ulak and
Nakayama 2001; Szulc et al. 2006). Petrographic and isotopic analyses from the Karnali section also indicate the earlier supply of detritus from both the Higher and Lesser Himalaya (DeCelles et al. 1998; Huyghe et al. 2001, 2005; Szulc et al. 2006), suggesting the sediments were supplied from a large catchment system, probably the paleo-Karnali River.

The reason why the flood-flow dominated river system developed earlier in the Karnali River section than in the central and eastern parts of the Nepalese Siwalik remains unclear, however. As noted above, the Karnali River section contains sediments that were deposited mainly from a large catchment system. The Karnali section thus provides a record of regional climate, and hence the increase in water discharge around 13.5 Ma can be interpreted to have been due to intensification of the Indian Summer Monsoon (Ulak and Nakayama 2001). Earlier uplift in the western part of the Nepal Himalaya may also have caused higher orographic rainfall in this region. Ojha et al. (2000) reported the magnetostratigraphy of the Khutia Khola section, which is located about $50 \mathrm{~km}$ west of the Karnali River (Fig. 1), and showed that the age of base of the Middle Siwalik was about $11.05 \mathrm{Ma}$ which is $1.5 \mathrm{Ma}$ earlier than the Karnali River section. According to their lithological description, muddy facies predominate in the Lower Siwalik in Khutia Khola. Consequently, it is probable that the Khutia Khola succession was deposited from smaller river systems than was the case in the Karnali River section. In general, the Middle Siwalik are the deposits of braided streams, and they contain detrital grains (salt and pepper) derived from the Higher Himalayas. Although it is difficult to discuss the timing of the alluvial fan development in the Siwalik successions associated with the Himalayan uplift without three dimensional distributions of the alluvial fan facies (c.f. Burbank 1992), the earlier appearance of the alluvial fan facies (Middle Siwalik) in the Khutia Khola section together with supply of detritus from the Higher Himalayas implies that early uplift of that source may have promoted erosion, even in small river systems in the western Nepal Himalaya. Therefore, the early uplift of the western part of Nepal Himalaya may have caused change in the climatic pattern (monsoonal precipitation) earlier than in the central and eastern parts. The early uplift is contemporaneous with increased exhumation rate of the Higher Himalaya (Szulc et al. 2006) recorded in the Karnali section. Several other studies have identified diachronous uplift and exhumation of the Nepal Himalaya, with earlier uplift and exhumation in the western part (Arita and Ganzawa 1997; Szulc et al. 2006; Bernet et al. 2006; Chirouze et al. 2012). As discussed above, the climate change at $13.5 \mathrm{Ma}$ is a response to early uplift of the western Nepal Himalaya. Integrated study of uplift of the western Himalaya at that time and related climate change is lacking to date. However, Liu et al. (2009) showed that extension of drier areas in western China and restriction of humid areas to southern China during the late middle Miocene (13.5 Ma) may reflect the early uplift of the western Himalaya. This uplift blocked deep penetration of wind jet streams originating from the Indian Ocean to the Tibetan Plateau, creating a rain shadow zone in western China (drier area) and 


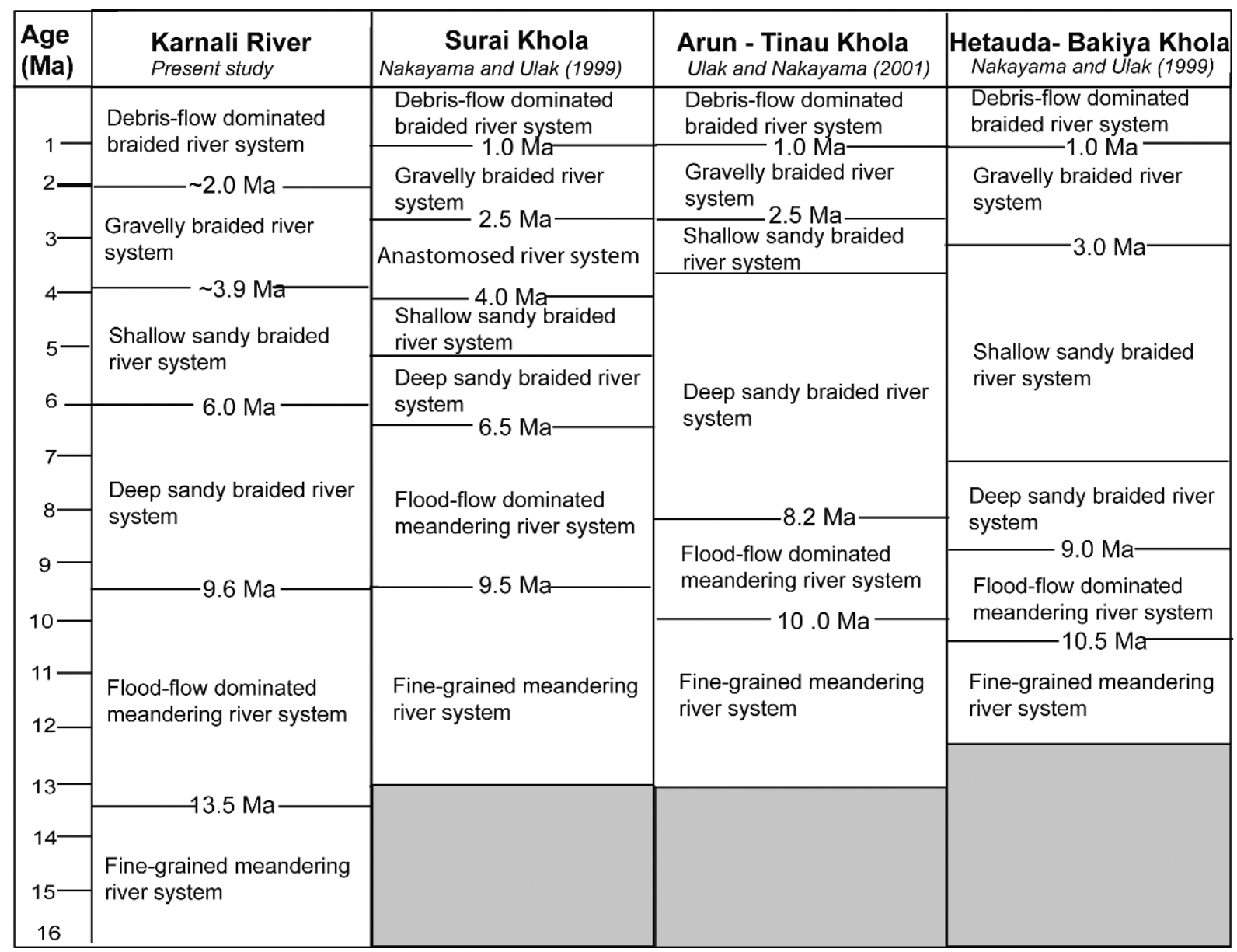

Fig. 15: Comparison of the fluvial systems in different sections of the Siwalik Group of the Nepal Himalaya.

wet and humid climate in the frontal Himalaya, and associated intensification of the Indian Summer Monsoon.

\section{CONCLUSIONS}

Twelve lithofacies and six facies associations were identified in the Siwalik Group along the Karnali River section, based on detailed and refined facies analysis. The individual facies associations represent a fine-grained meandering river system (FA1) flood-flow dominated meandering river system with intermittently appeared braided river facies (FA2), deep and shallow sandy braided river systems (FA3 and FA4, respectively), followed by a gravelly braided river system (FA5) and a debris flow-dominated braided river system (FA6), in ascending order. Huyghe et al. (2005) proposed the floodflow dominated meandering system (their KFA2) and sandy flood-flow dominated meandering system (their KFA3) in the upper part of middle and upper members of the Chisapani Formation, and an anastomosed river system (KFA6), in the upper member of Baka Formation, However, we reinterpreted these deposits as a flood-flow dominated meandering system with intermittent appearance of braided river system (FA2). We identified a shallow sandy braided river system (FA4) in the upper member of Baka Formation, rather than the anastomosed river system proposed by Huyghe et al. (2005).

The paleomagnetic dating by Gautam and Fujiwara (2000) and our reconstructed fluvial systems show that major changes in the fluvial systems occurred at around 13.5 Ma and 9.6 Ma. The change from a fine-grained meandering system to a floodflow dominated meandering system at $13.5 \mathrm{Ma}, 0.4 \mathrm{Ma}$ earlier than proposed by Huyghe et al. (2005), and 3-4 Ma earlier than in other Siwalik sections. This change arose from increased flood in river channels due to increased water discharge, due to early uplift in the catchment basin which induced a change of precipitation pattern i.e. intensification of Indian Summer Monsoon. Similarly, appearance of the braided river facies (salt and pepper sandstones) at 9.6 Ma in the Karnali River suggests supply of detritus from the Higher Himalayas implies that early uplift of the source area. The early uplift and erosion of the Higher Himalaya in western Nepal may thus have played a significant role in changing climate, as well as changing the fluvial depositional systems.

\section{ACKNOWLEDGEMENTS}

We thank Biraj Gautam, Basanta R. Adhikari, Prabhat C. Neupane, Trilok C. Bhatta, Hitendra R. Joshi, Lalit Rai, and Ajit Sapkota for their assistance during fieldwork. We also thank to B. P. Roser for critical reading and helpful comments on early version of manuscript and the Ministry of Education, Culture, Science and Technology of Japan for granting a Monbukagakusho (MEXT) scholarship for Ph.D. study to the first author. 


\section{REFERENCES}

Allen, J. R. L., 1983, Studies in fluviatile sedimentation: bars, bar complexes and sandstone sheets (low-sinuosity braided streams) in the Brownstones (L. Devonian), Welsh Borders. Sed. Geol., v. 33, pp. 237-293.

Amatya, K. M., Jnawali, B. M., 1994, Geological map of Nepal (Scale 1:1000,000). Dept. Mines and Geol. (DMG), Kathmandu, Nepal.

Arita, K., Ganzawa, Y., 1997, Thrust tectonics and uplift of the Nepal Himalaya revealed from fission-track ages. Jour. Geogr., v. 106, pp. 156-167.

Bhattacharya, A., Morad, S., 1993, Proterozoic braided ephemeral fluvial deposits: an example from the Dhandraul Sandstone Formation of the Kaimur Group, Son Valley, central India. Sed. Geol., v. 84, pp. 101-114.

Bernet, M., Van Der Beek, P., Pik, R., Huyghe, P., Mugnier, J. L., Labrin, E., Szulc, A. G., 2006, Miocene to recent exhumation of central Himalaya determined from combined detrital zircon fission-track and $\mathrm{U} / \mathrm{Pb}$ analysis of Siwalik sediments, western Nepal. Basin Res., v. 18, pp. 393-412.

Blair, T. C., McPherson, J. G., 1998, Recent debris-flow processes and resultant form and facies of the Dolomite alluvial fan, Owens Valley, California. Jour. Sed. Res., v. 68, pp. 800-818.

Bordy, E. M., Catuneanu, O., 2001, Sedimentology of the upper Karoo fluvial strata in the Tuli Basin, South Africa. Jour. African Earth Sci., v. 33, pp. 605-629.

Bourquin, S., Guillocheau, F., Pe'ron, S., 2009, Braided rivers within an arid alluvial plain (example from the Lower Triassic, western German Basin): recognition criteria and expression of stratigraphic cycles. Sedimentology, v. 56, pp. 2235-2264.

Bridge, J. S., Tye, R. S., 2000, Interpreting the dimensions of ancient fluvial channel bars, channels, and channel belts from wireline logs and cores. American Assoc. Pet. Geol. Bull., v. 84, pp. 1205-1228.

Bridge, J. S., 2003, Rivers and Flood plain, Backwell Scientific, Oxford, $504 \mathrm{p}$.

Bridge, J. S., 2006, Fluvial facies models: recent developments. In: Posamentier, H., Walker, R.G. (Eds.), Facies Models Revisited. SEPM (Soc. Sed. Geol.) Special Publ., v. 84, pp. 85-170.

Brierley, G. J., Liu, K., Crook, K. A. W., 1993, Sedimentology of coarse-grained alluvial fans in the Markham Valley, Papua New Guinea. Sed. Geol., v. 86, pp. 297-323.

Bristow, C. S., 1993, Sedimentology of the Rough Rock: a Carboniferous braided river sheet sandstone in northern England, in Best, J. L., and Bristow, C.S., eds., Braided Rivers: Geol. Soc. Sp. Publ., v. 75, pp. 291-304.

Burbank, D. W., 1992, Cause of recent Himalayan uplift deduce from deposited pattern in the Ganga basin. Nature 357, pp. 680-683.

Cande, S. C., Kent, D. V., 1995, Revised calibration of the geomagnetic polarity time scale for the late Cretaceous and Cenozoic. Jour. Geophy. Res., v. 100(B4), pp. 6093-6095.

Chirouze, F., Bernet, M., Huyghe, P., Erens V., Dupont-Nivet, G., Senebier, F., 2012, Detrital thermochronology and sediment petrology of the middle Siwaliks along the Muksar Khola section in eastern Nepal. Jour. Asian Earth Sci., v. 44, pp. 94 106.

Collinson, J. D., 1986, Alluvial Sediments, In: H. G. Reading (Ed.) Sedimentary Environments and Facies, 2nd Ed., Blackwell, Oxford, pp. 20-62.

DeCelles, P. G., Gehrels, G. E., Quade, J., Ojha, T. P., Kapp, P. A., Upreti, B. N., 1998, Neogene foreland basin deposits, erosional unroofing, and the kinematic history of the Himalayan foldthrust belt, western Nepal. Geol. Soc. America Bull. v. 110, pp. $2-21$.

Department of Mines and Geology (DMG/HMGN), 1987, Geological Map of Far Western Nepal, 1:250,000.

Department of Mines and Geology (DMG/HMGN), 2003, Geological Map of Petroleum Exploration Block-2, Karnali, Far Western Nepal, 1:250,000.

Gansser, A., 1964, Geology of the Himalayas. Interscience, London, $289 \mathrm{p}$.

Gautam, P., Fujiwara, Y., 2000, Magnetic polarity stratigraphy of Siwalik Group sediments of the Karnali River section in western Nepal. Geophy, Jour. Int., v. 142, pp. 812-824.

Godin, P. D. 1991, Fining-upward cycles in the sandy braided-river deposits of the Westwater Canyon Member (Upper Jurassic), Morrison Formation, New Mexico. Sed. Geol., v. 70, pp. 61-82.

Hampton, B. A., Horton, B. K., 2007, Sheetflow fluvial processes in a rapidly subsiding basin, Altiplano plateau, Bolivia. Sedimentology, v. 54, pp. 1121-1147.

Hartley, A. J., 1993, Sedimentological response of an alluvial system to source area tectonism: the Seilao Member of the Late Cretaceous to Eocene Purilactis Fm. of Northern Chile. Int. Assoc. Sed., Sp. Publ., v. 17, pp. 489-500.

Hisatomi, K. and Tanaka, S. 1994, Climatic and environmental changes at 9.0 and 7.5 Ma in the Churia (Siwalik) Group, West Central Nepal. Himalayan Geol., v. 15, pp. 161-180.

Hjellbakk, A., 1997, Facies and fluvial architecture of a high-energy braided river: the Upper Proterozoic Seglodden Member, Baranger Peninsula, northern Norway. Sedimentary Geol., v. 114, pp. 131-161.

Huyghe, P., Galy, A., Mugnier, J. L., France-Lanord, C., 2001, Propagation of the thrust system and erosion in the Lesser Himalaya: Geochemical and sedimentological evidence. Geol., v. 29 , pp. $1007-1010$.

Huyghe, P., Mugnier, J. L., Gajurel, A. P., Decaillau, B., 2005, Tectonic and climatic control of the changes in the sedimentary record of the Karnali River section (Siwaliks of western Nepal). Island Arc, v. 14, pp. 311-327.

Johnson, A. M., 1970, Physical Processes in Geology: San Francisco (Freeman, Cooper and Co.) $577 \mathrm{p}$.

Khadkikar, A. S., Nathew, G., Malik, J. N., Gunda Rao, T. K., Chogaonkar, M. P., Merh, S. S., 1999, The influence of the South-west Indian Monsoon on continental deposition over past 130 kyr, Gujarat, western India. Terra Nova, v. 11, pp. 273-277.

Khan, I. A., Bridge, J. S., Kappelman, J., Wilson, R., 1997, Evolution of Miocene fluvial environments, eastern Potwar Plateau, northern Pakistan. Sedimentology, v. 44, pp. 221-251.

Kumar, R., Nanda, A. C., 1989, Sedimentology of the Middle Siwalik Subgroup of Mohand area, Dehara Dun valley, India. Geol. Soc. India, v. 34, pp. 597-616.

Kumar, R., Ghosh, S. K. Sangode, S. J., 2003, Mio-Pliocene sedimentation history in the northwestern part of the Himalayan foreland basin, India. Current Science, v. 84, pp. 1006-1013.

Kumar, R., Sangode, S. J., Ghosh, S. K., 2004, A multistorey sandstone complex in the Himalayan Foreland Basin, NW Himalaya, India. Jour. Asian Earth Sci, v. 23, pp. 407-426.

Liu, L., Eronen J. T., Fortelius M., 2009, Significant mid latitude aridity in the middle Miocene of East Asia. Palaeogeo., Palaeoclim., Palaeoeco., v. 279, pp. 201-206.

Lunt, I. A, Bridge, J. S., Tye, R. S. 2004, A quantitative, three dimensional depositional model of gravelly braided rivers. 
Sedimentology, v. 51, pp. 377-414.

Maizels, J. K., 1989, Sedimentology, paleoflow dynamics and flood history of jökulhlaup deposits: paleohydrology of Holocene sediment sequences in southern Iceland sandur deposits. Jour. Sed. Pet., v. 59, pp. 204-223.

Maizels, J. K. 1993, Lithofacies variations within sandur deposits: the role of runoff regime, flow dynamics and sediment supply characteristics. Sed. Geol., v. 85, pp. 299-325.

Miall, A. D., 1977, A review of the braided river depositional environment. Earth Sci. Rev. v. 13, pp. 1-62.Miall, A.D., 1978, Lithofacies types and vertical profile models in braided river deposits: a summary. In: A. D. Miall (Editor), Fluvial Sedimentology. Canadian Soc. Petroleum Geol. Memoir, v. 5, pp. 597-604.

Miall, A. D., 1985, Architectural-element analysis: a new method of facies analysis applied to fluvial deposits. Earth Sci. Rev., v. 22, pp. 261-308.

Miall, A. D., 1990, Principles of Sedimentary Basin Analysis. Second Edition, Springer, $668 \mathrm{p}$.

Miall, A. D., 1996, The Geology of Fluvial Deposits: Sedimentary Facies, Basin Analysis, and Petroleum Geology. SpringerVerlag, New York, $582 \mathrm{p}$.

Mugnier, J. L., Delcaillau, B., Huyghe, P., Leturmy, P., 1998, The break-back thrust splay of the Main Dun Thrust (Himalayas of western Nepal): evidence of an intermediate displacement scale between earthquake slip and finite geometry of thrust systems. Jour. Struc. Geol., v. 20, pp. 857-864.

Mugnier, J. L., Leturmy, P., Mascle, G., Huygle, P., Chalaron, E., Vidal, G., Husson, L. Delcaillau, B., 1999, The Siwalik of Western Nepal: I. geometry and kinematics. Jour. Asian Earth Sci., v. 17, pp. 629-642.

Nakayama, K. and Ulak, P. D., 1999, Evolution of fluvial style in the Siwalik Group in the foothills of the Nepal Himalaya. Sed. Geol., v. 125, pp. 205-224.

Ojha, T. P., Butler, R. F., Quade, J., DeCelles, P. G., Richards, D., Upreti, B. N. 2000, Magnetic polarity stratigraphy of the Neogene Siwalik Group at Khutia Khola, far-western Nepal. Geol. Soc. America Bull., v. 112, pp. 424-434.

Olsen, H., 1988, The architecture of a sandy braided-meandering river system: an example from the Lower Triassic Solling Formation (M.Buntsandstein) in W-Germany. Geol. Rund., v. 77, pp. 797814.

Pandita, S. K., Bhat S. K., Kotwal S. S., 2011, Facies evaluation of Boulder Conglomerate Formation, Upper Siwalik, Jammu Himalaya. Himalayan Geol., v. 32, pp. 63-69.

Patriat, P., Achache, J., 1984, India-Eurasia collision chronology has implications for crustal shortening and driving mechanism of plates. Nature, 311, pp. 615-621.

Peakall, J., Philip, J., Best J. L., 2007, Meander-bend evolution, alluvial architecture, and the role of cohesion in sinuous river channels. Jour. Sed. Res., v. 77, 197-212.

Prakash, B., Sharma, R. P., Roy, A. K., 1980, The Siwalik Group (molasse) sediments shed by collision of continental plates. Sed. Geol., v. 25, pp. 127-159.

Retallack, G. J., 1991, Miocene Paleosols and Ape Habitats of Pakistan and Kenya. Oxford University Press, 346 p.

Roe, S. L., Hermansen, M., 1993, Processes and products of large, Late Precambrian sandy rivers in northern Norway. Int. Assoc. Sedimentology., Sp. Publ., v. 17, pp. 151-166.

Rowley, D. B., 1996, Age of initiation of collision between India and Asia: a review of stratigraphic data. Earth Planet. Sci. Let., v. 145 , pp. 1-13.
Rust, B. R., Gibling, M. R., Legun, A. S., 1984, Coal Deposition in an anastomosing-fluvial system: the Pennsylvanian Cumberland Group south of Joggins, Nova Scotia, Canada. Int. Assoc. Sedimentology., Sp. Publ., v. 7, pp. 105-120.

Sakai, T., Saneyoshi, M., Tanaka, S., Sawada, Y., Nakatsukasa, M., Mbua, E., Ishida, H., 2010, Climate shift recorded at around 10 $\mathrm{Ma}$ in Miocene succession of Samburu Hills, northen Kenya Rift, and its significance. Geol. Soc. London, Sp. Publ., v. 342, pp. 109-127.

Sharma, M., Sharma, S., Shukla U. K., Singh, I. B., 2002, Sandstone body architecture and stratigraphic trends in the Middle Siwalik Succession of the Jammu area, India. Jour. Asian Earth Sci., v. 20, pp. 817-828.

Sigdel, A., Sakai T., Ulak, P. D., Gajurel A. P., Upreti, B. N., 2011, Lithostratigraphy of the Siwalik Group, Karnali River section, far-west Nepal Himalaya. Jour. Nepal Geol. Soc., v. 43 (Sp. Issue), pp. 83-101.

Smith, N. D., 1972, Some sedimentological aspects of planar crossstratification in a sandy braided river. Jour. Sed. Pet., v. 42, pp. 624-634.

Szulc, A. G., Najman, Y., Sinclair, H., Pringle, M., Bickle, M., Chapman, H., Garzanti, E., Ando, S., Huyghe, P., Mugnier, J. L., Ojha, T. P., DeCelles, P. G. 2006, Tectonic evolution of the Himalaya constrained by detrital 40Ar-39Ar, Sm-Nd and petrographic data from the Siwalik foreland basin succession, SW Nepal. Basin Res., v. 18, pp. 375-391.

Tanaka, S. 1997, Uplift of the Himalaya and climate changes at 10.0 Ma evidence from records of the carbon stable isotopes and fluvial sediments in the Churia Group Nepal. Jour. Geol. Soc. Japan, v. 103(3), pp. 253-264.

Tokuoka, T., Takayasu, K., Yoshida, M. and Hisatomi, K., 1986, The Churia (Siwalik) Group of Arung Khola area, west-central Nepal. Memoirs of the Faculty of Science, Shimane University, v. 22, pp. 135-201.

Tokuoka, T., Takayasu, K., Hisatomi, K., Yamasaki, H., Tanaka, S., Konomatsu, M., Sah, R. B., and Roy, S. M., 1990, The Churia (Siwalik) Group of Tinau Khola-Binai Khola area, west-central Nepal. Memoirs of the Faculty of Science, Shimane University, v. 24, pp. 71-88.

Tokuoka, T., Takayasu, K., Hisatomi, K., Tanaka, S., Yamasaki, H., Konomatsu, M., 1994, The Churia Siwalik Group in West Central Nepal. Himalayan Geol., v. 15, pp. 23-35.

Ulak, P. D., Nakayama, K., 2001, Neogene fluvial systems in the Siwalik Group along Tinau Khola section, west central Nepal Himalaya. Jour. Nepal Geol. Soc., v. 25, pp. 111-122.

Upreti, B. N., 1999, An overview of stratigraphy and tectonics of the Nepal Himalaya. Jour. Asian Earth Sci., v. 17, pp. 577-606.

Van Der Beek, P., Robert, X., Mugnier, J. L., Bernet, M., Huyghe, P., and Labrin, E. 2006, Late Miocene-Recent exhumation of central Himalaya and recycling in the foreland basin assessed by apatite fission track thermochronology of Siwalik Sediments, Nepal. Basin Res., v. 18, pp. 413-434.

Willis, B. J., 1993, Evolution of Miocene fluvial systems in the Himalayan foredeep through a two-kilometer-thick succession in northern Pakistan. Sed. Geol., v. 88, pp. 77-121.

Zaleha, M. J., 1997, Intra-and extrabasinal controls on fluvial deposition in the Miocene Indo Gangatic foreland basin, northern Pakistan. Sedimentology, v. 44, pp. 369-390. 